\title{
16. PLANKTONIC FORAMINIFERAL BIOSTRATIGRAPHY OF EASTERN EQUATORIAL PACIFIC SEDIMENTS, DEEP SEA DRILLING PROJECT LEG 85 $^{1}$
}

\author{
Tsunemasa Saito, Department of Earth Sciences, Yamagata University ${ }^{2}$
}

\begin{abstract}
Tropical planktonic foraminifers occur throughout the sequences at all sites of Leg 85, and the standard planktonic foraminiferal zonation of Blow (1969) is applicable to most of the recovered sequences. However, the abundance and state of preservation of foraminifers decline markedly in certain intervals because of the effects of dissolution. Although siliceous microfossils studied on this leg indicate recovery of nearly complete records for the Pleistocene to Oligocene interval, the planktonic foraminiferal biostratigraphy is interrupted by strongly dissolved sections at all sites. Particularly, faunas assignable to Zone N7 (early Miocene) and Zone N15-16 (early late Miocene) are almost totally unrecognizable throughout the eastern equatorial Pacific. Well-preserved and diverse planktonic foraminifers occur in the lower middle Miocene, where the evolutionary developments of Orbulina universa d'Orbigny and Globorotalia fohsi Cushman and Ellisor are well represented. The Orbulina first appearance datum is observed to be nearly coincident with the last occurrence level of the diatom Annellus californicus Tempère, thus establishing an age of $15 \mathrm{Ma}$ for this datum by using the paleomagnetic calibration of the diatom datum. Moderately well-preserved late Eocene planktonic foraminifers occur in the carbonate sediments immediately overlying the basalt basement at Sites 573 and 574. The Eocene-Oligocene faunal transition, however, is masked at both sites by an intercalation of metalliferous layers containing no planktonic foraminifers.
\end{abstract}

\section{INTRODUCTION}

With the use of a newly developed hydraulic piston corer (HPC), Leg 85 attempted to recover from the eastern equatorial Pacific undisturbed Cenozoic sequences suitable for high-resolution biostratigraphy. The region covered by Leg 85 is in the equatorial high-productivity zone, where steady accumulation of siliceous and carbonate shells of planktonic microorganisms has created a belt of thick sediment piles on the seafloor. The crest of this belt lies slightly north of the equator $\left(4^{\circ} \mathrm{N}\right.$ at $180^{\circ} \mathrm{W}$ ) and trends toward the equator to the east. Four earlier DSDP cruises (Legs 5, 8, 9, and 16) drilled into this belt of sediment piles, and Leg 85 established five additional drill sites (Fig. 1 and Table 1).

A large body of knowledge now exists on the planktonic foraminiferal biostratigraphy of this region. Although the pioneering work of the Swedish Deep Sea Expedition was the first to thoroughly describe the sediment types of this region, it was Parker (1967) who first established a planktonic foraminiferal zonation for the upper Miocene to Pleistocene sediments of the tropical Pacific region. Subsequent studies by Hays et al. (1969) and Saito et al. (1975) integrated microfaunal successions with geomagnetic reversal sequences down to upper Miocene and were able to paleomagnetically calibrate microfossil first and last appearances within a time resolution of several hundred thousand years. These earlier studies are all based on piston cores, and hence research was limited to upper Neogene sections.

\footnotetext{
${ }^{1}$ Mayer, L., Theyer, F., et al., Init. Repts. DSDP, 85: Washington (U.S. Govt. Printing Office).

Address: Department of Earth Sciences, Faculty of Science, Yamagata University, Yamagata, 990 Japan.
}

The first successful attempt to study older Cenozoic sediments in this belt of thick sediment piles was made during Leg 8 . Sediments as old as middle Eocene were recovered on this cruise by intermittent coring. Beckman (1971) described and illustrated most of the zonal marker species of planktonic foraminifers used for age determination. One nearly continuous calcareous record was obtained during Leg 9 from Hole 77B. The foraminiferal biostratigraphy of Hole 77B was initially described by Jenkins and Orr, who also illustrated many species (Jenkins and Orr, 1972, pls. 1 to 41 ). The sedimentary record at Hole 77B has since become a focus of intensive study by many micropaleontologists; six papers on planktonic foraminifers alone have been written, mostly by Keller and co-authors (cited in Keller and Barron, 1983).

Although the foraminiferal sequence at Hole 77B provides one of the few nearly complete Neogene faunal records, its foraminiferal assemblages are severely affected by dissolution. The effects of dissolution were such that Jenkins and Orr (1972) developed a new zonation (distinct from the one defined by Blow [1969]), which was largely based on solution-resistant species. Keller (1980, 1981), however, was able to apply Blow's zones to at least the Miocene sequence.

Dissolution of planktonic foraminifers is also a factor in most of the sequences cored during Leg 85. One exception is the lower middle Miocene interval covering the evolutionary development of Globorotalia fohsi and its subspecies from their ancestor G. peripheroronda. To aid age assignments and comparisons of the results of Leg 85 with studies of other areas, I have applied, as well as possible, the standard zonation of Blow (1969) to the planktonic foraminiferal assemblages in Leg 85 samples. There are a few instances, however, where I have used a second-order correlation to approximate the 


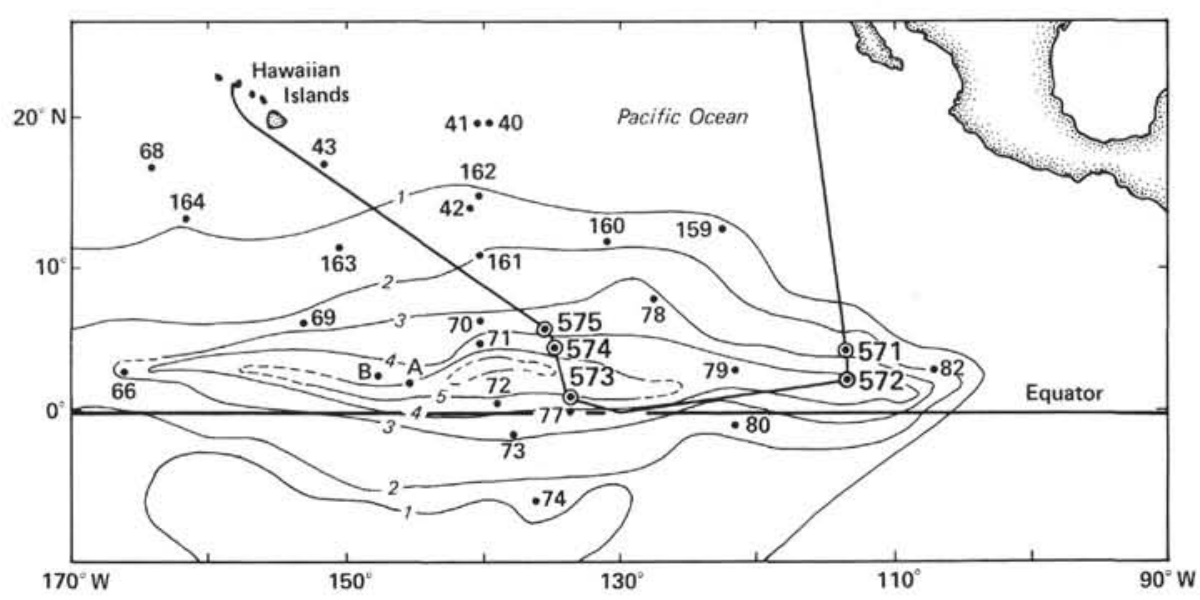

Figure 1. Cruise track and locations of Leg 85 drill sites in the eastern equatorial Pacific. Contours in tenths of seconds of two-way traveltime. Previous holes drilled on Legs 5 (Sites 40-43), 8 (Sites 66-74), 9 (Sites 77-82), and 16 (Sites 159-164) are also shown, in addition to the locations of two piston cores, V24-59 (A) and RC12-66 (B), for which Hays et al. (1969) and Saito et al. (1975), respectively, established a combined microfossil and paleomagnetic stratigraphy.

Table 1. Leg 85 site data.

\begin{tabular}{lcccccrl}
\hline Hole & Latitude & Longitude & $\begin{array}{c}\text { Water } \\
\text { depth }\end{array}$ & $\begin{array}{c}\text { Sub-bottom } \\
\text { depth } \\
(\mathrm{m})\end{array}$ & $\begin{array}{c}\text { Number } \\
\text { of cores }\end{array}$ & $\begin{array}{c}\text { Total sediment } \\
\text { recovered } \\
(\mathrm{m})\end{array}$ & $\begin{array}{c}\text { Oldest } \\
\text { sediment } \\
\text { cored }\end{array}$ \\
\hline 571 & $03^{\circ} 59.84^{\prime} \mathrm{N}$ & $114^{\circ} 08.53^{\prime} \mathrm{W}$ & 3962 & $0-7.11$ & 1 & 7.11 & Pleistocene \\
572 & $01^{\circ} 26.09^{\prime} \mathrm{N}$ & $113^{\circ} 50.52^{\prime} \mathrm{W}$ & 3893 & $0-18.7$ & 2 & 9.25 & Pleistocene \\
$572 \mathrm{~A}$ & $01^{\circ} 26.09^{\prime} \mathrm{N}$ & $113^{\circ} 50.52^{\prime} \mathrm{W}$ & 3893 & $0-154$ & 17 & 154.35 & up. Miocene \\
$572 \mathrm{~B}$ & $01^{\circ} 26.09^{\prime} \mathrm{N}$ & $113^{\circ} 50.52^{\prime} \mathrm{W}$ & 3893 & $154-169.4$ & 4 & 19.95 & up. Miocene \\
$572 \mathrm{C}$ & $01^{\circ} 26.09^{\prime} \mathrm{N}$ & $113^{\circ} 50.52^{\prime} \mathrm{W}$ & 3893 & $0-169.5$ & 20 & 161.56 & up. Miocene \\
$572 \mathrm{D}$ & $01^{\circ} 26.09^{\prime} \mathrm{N}$ & $113^{\circ} 50.52^{\prime} \mathrm{W}$ & 3893 & $151-489.0$ & 34 & 258.87 & mid. Miocene \\
573 & $00^{\circ} 29.91^{\prime} \mathrm{N}$ & $133^{\circ} 18.57^{\prime} \mathrm{W}$ & 4301 & $0-158.6$ & 19 & 159.4 & up. Miocene \\
$573 \mathrm{~A}$ & $00^{\circ} 29.91^{\prime} \mathrm{N}$ & $133^{\circ} 18.57^{\prime} \mathrm{W}$ & 4301 & $14.0-57.7$ & 6 & 53.5 & low. Pliocene \\
$573 \mathrm{~B}$ & $00^{\circ} 29.91^{\prime} \mathrm{N}$ & $133^{\circ} 18.57^{\prime} \mathrm{W}$ & 4301 & $138.5-529.0$ & 43 & 279.7 & up. Eocene \\
574 & $04^{\circ} 12.52^{\prime} \mathrm{N}$ & $133^{\circ} 19.81^{\prime} \mathrm{W}$ & 4561 & $0-206.5$ & 31 & 208.93 & low. Miocene \\
$574 \mathrm{~A}$ & $04^{\circ} 12.52^{\prime} \mathrm{N}$ & $133^{\circ} 19.81^{\prime} \mathrm{W}$ & 4561 & $6.0-186.2$ & 23 & 180.74 & low. Miocene \\
$574 \mathrm{~B}$ & $04^{\circ} 12.52^{\prime} \mathrm{N}$ & $133^{\circ} 19.81^{\prime} \mathrm{W}$ & 4561 & $185.0-194.0$ & 1 & 9.45 & low. Miocene \\
$574 \mathrm{C}$ & $04^{\circ} 12.53^{\prime} \mathrm{N}$ & $133^{\circ} 19.81^{\prime} \mathrm{W}$ & 4561 & $194.5-532.5$ & 37 & 197.35 & low. Eocene \\
575 & $05^{\circ} 51.00^{\prime} \mathrm{N}$ & $135^{\circ} 02.16^{\prime} \mathrm{W}$ & 4536 & $0-98.6$ & 11 & 99.35 & low. Miocene \\
$575 \mathrm{~A}$ & $05^{\circ} 51.00^{\prime} \mathrm{N}$ & $135^{\circ} 02.16^{\prime} \mathrm{W}$ & 4536 & $93.8-208.4$ & 33 & 140.53 & low. Miocene \\
$575 \mathrm{~B}$ & $05^{\circ} 51.00^{\prime} \mathrm{N}$ & $135^{\circ} 02.16^{\prime} \mathrm{W}$ & 4536 & $3.3-119.0$ & 14 & 118.68 & low. Miocene \\
$575 \mathrm{C}$ & $05^{\circ} 51.00^{\prime} \mathrm{N}$ & $135^{\circ} 02.16^{\prime} \mathrm{W}$ & 4536 & $0-15.8$ & 2 & 15.91 & up. Miocene \\
\hline
\end{tabular}

standard zonal boundary. Tables 2 through 6 present the stratigraphic distribution of planktonic foraminifers, their state of preservation, and abundances. Since so much is already known about the planktonic foraminifers of this region, only a few taxonomic comments are added to those taxa pertinent to discussion (see Appendix), and the plate illustrations cover only selected species.

\section{METHODS}

The planktonic foraminiferal biostratigraphy presented in this paper is based primarily on the onboard examination of core-catcher samples. When a foraminiferal zone boundary occurred between two core-catcher samples, additional samples from each core section were examined on shore to narrow the boundary. Samples of approximately $10 \mathrm{~cm}^{3}$ were washed through a 250 -mesh screen $(0.62-\mu \mathrm{m}$ opening $)$ and dried. Unconsolidated sediments were soaked in water, and when necessary, disaggregation was facilitated by the addition of small amounts of hydrogen peroxide. Hydrogen peroxide was also routinely added to more consolidated sediments. Much more consolidated or semi-indurated sediments encountered in the lower parts of the sedimentary columns were disaggregated by using a petroleum solvent, Varsol or Naphtha. In this technique, samples are thoroughly oven dried at about $130^{\circ} \mathrm{C}$ and are soaked with the solvent while they are still hot. After the excess fluid is drained, the solvent-soaked sediments are boiled in water containing a small quantity of sodium metaphosphate until complete disaggregation occurs. In the final washing process, the solvent can be easily driven off from both the sample and the washing screen by applying a jet of multisurface spray cleaner, such as Fantastik.

Quantitative analyses of species abundance shown in Tables 2 through 6 were made with the aid of the visual percentage estimation chart of Terry and Chilingar (1955; reproduced in Scholle, 1979, p. vii). (See the footnotes to Tables 2 and 3 for explanations of the abbreviations.)

I have attempted to graphically illustrate the varying degrees of foraminiferal dissolution by calculating for each assemblage the 10-point foraminifer solution code of Berger and von Rad (1972), in which a high solution-code number indicates stronger dissolution. These plots can be found in the site chapters and are not reproduced here.

Saito (1976) showed that systematic changes with time in the coiling direction of the planktonic foraminiferal genus Pulleniatina provide useful datum levels for interregional correlation of Pliocene-Pleistocene sediments. To establish additional criteria for the biostratigraphy, counts of Pulleniatina coiling direction were made for Holes $572 \mathrm{C}$ and 573 (Fig. 2). More than 100 specimens were randomly picked whenever possible from each assemblage, and the percentages of rightcoiling and left-coiling individuals were determined. 
Table 2. Occurrence and estimated abundance of planktonic foraminifers at Site 571.

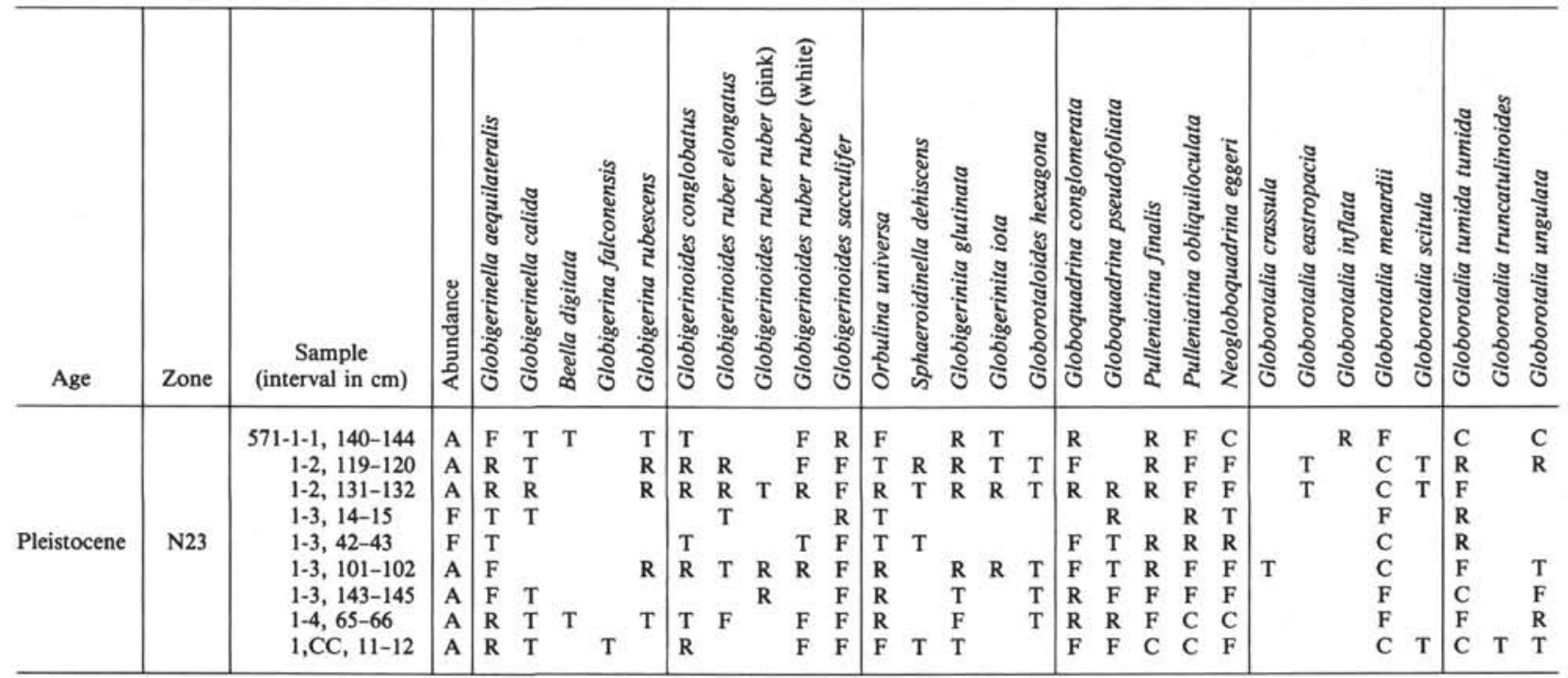

Note: $\mathrm{A}=$ abundant $(>10 \%$ of assemblage); $\mathrm{C}=$ common $(3-10 \%) ; \mathrm{F}=$ few $(0.5-3 \%) ; \mathrm{R}=$ rare $(<0.5 \%) ; \mathrm{T}=$ trace (only one or two specimens in entire assemblage).

\section{MODIFICATION TO THE STANDARD ZONATION}

The dissolution of planktonic foraminifers observed in certain intervals of the sequences recovered on Leg 85 necessitates a second-order correlation to approximate the standard zonal boundary proposed by Blow (1969).

I have placed the top boundary of Zone N19 at the extinction level of Sphaeroidinellopsis seminulina (Schwager). This cortex-covered species is fairly resistant to solution and provides a reliable correlation datum. The top of Zone N19 was initially defined by Banner and Blow (1965) as the last occurrence level of Globoquadrina altispira (Cushman and Jarvis). According to the paleomagnetic stratigraphy of Saito et al. (1975), the extinction level of $S$. seminulina occurs at the top of the Mammoth Subchron (3.08 Ma) and that of G. altispira at the top of the Kaena Subchron (2.92 Ma), both in the Gauss Chron. They are indeed very close. Furthermore, I have excluded Zone N20 from the Leg 85 sequences for several reasons. In their initial proposal of the Neogene numerical zonation, Banner and Blow (1965) defined Zone N20 to be the interval following the extinction of G. altispira and before the first appearance of $G$. tosaensis. Both Parker (1967) and Hays et al. (1969), however, showed that the ranges of these two species actually overlap in the tropical Indo-Pacific, which precludes the establishment of a zone based on the absence of these two species. Blow (1969) subsequently redefined Zone N20 by introducing two new subspecies, Globorotalia acostaensis pseudopima and $G$. tosaensis tenuitheca. The first occurrence of the former defines the lower limit of the zone, and the first occurrence of the latter marks the upper limit. Blow (1970) further justified his 1969 redefinition in yet another discussion on the standard zonation. This definition of Zone N20, however, poses two correlation problems. One is the uncertainty of taxonomically recognizing these two zonal index taxa, both of which were erected at a subspecific level. The second is the stratigraphic position of the zonal reference section chosen for Zone N20. Blow (1969) designated the locality and level of Sample ER.156, within the Bowden Formation of Jamaica, West Indies, as the primary reference section. The prefix "ER." stands for E. Robinson of the University of the West Indies, who collected samples for Blow and who described the Neogene section of Jamaica (Robinson, 1969). I have examined planktonic foraminifers of this sample, which was kindly supplied by Dr. Robinson, and found among others Globorotalia crassaformis (Galloway and Wissler), G. exilis Blow, $G$. miocenica Palmer, G. truncatulinoides (d'Orbigny), Neogloboquadrina dutertrei (d'Orbigny), and Globigerinoides fistulosus (Schubert). The joint occurrence of Globorotalia exilis, G. miocenica, and $G$. truncatulinoides enables a correlation of Sample ER.156 with the uppermost Matuyama Chron of the paleomagnetic stratigraphy at about the Olduvai Subchron. Zone N21 is, however, defined as the interval prior to the first appearance of $G$. truncatulinoides, an event that occurred shortly before Olduvai Subchron time. Thus, the Zone N20 reference section is in reality younger than Zone N21. To circumvent this stratigraphic dilemma, I excluded Zone N20 from the zonal scheme and placed Zone N21 to directly overlie Zone N19 at the extinction level of $S$. seminulina.

The first appearance level of Globigerinatella insueta Cushman and Stainforth occurs in a solution-affected interval at both Sites 574 and 575. This level defines the N5/N6 zonal boundary. The last appearance level of Globigerina binaiensis Koch is instead used to approximate this boundary. In carbonate-rich sequences, these two paleontologic events are shown to occur within a close stratigraphic interval (Srinivasan and Kennett, 1981).

Zone N4 as defined by Blow (1969) is the second example where his original definition came to be nonwork- 
Table 3A. Occurrence and estimated abundance of planktonic foraminifers, Holes 572 and 572A.

\begin{tabular}{|c|c|c|c|c|c|c|c|c|c|c|c|c|c|c|c|c|c|c|c|c|c|c|}
\hline Age & Zone & $\begin{array}{c}\text { Sample } \\
\text { (interval in } \mathrm{cm} \text { ) }\end{array}$ & 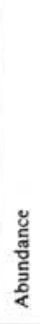 & oू & 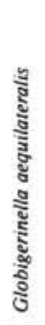 & 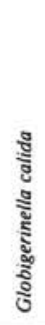 & 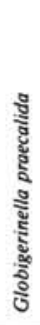 & 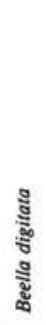 & 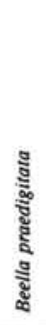 & 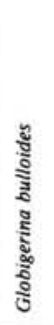 & 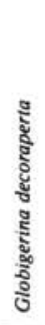 & 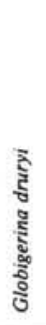 & 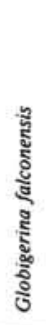 & 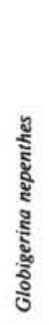 & 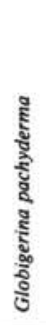 & 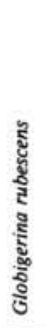 & 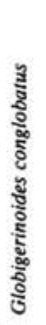 & 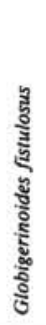 & 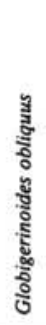 & 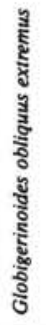 & 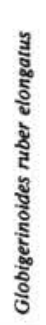 & 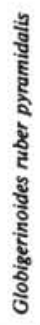 \\
\hline \multirow{4}{*}{ Quaternary } & $\mathrm{N} 23$ & $\begin{array}{l}\text { Hole } 572 \\
\begin{array}{l}1-1,2-5 \\
1-1,147-149 \\
1-2,147-149\end{array}\end{array}$ & $\begin{array}{l}\text { A } \\
\text { C } \\
\text { C }\end{array}$ & $\begin{array}{l}\mathrm{G} \\
\mathrm{G} \\
\mathrm{M}\end{array}$ & $\begin{array}{l}F \\
R\end{array}$ & $\begin{array}{l}\mathrm{T} \\
\mathrm{R} \\
\mathrm{T}\end{array}$ & & $\mathrm{T}$ & & & & & $\mathbf{R}$ & & $T$ & $\begin{array}{lll}T \\
\end{array}$ & $\begin{array}{l}\mathbf{R} \\
\mathbf{R} \\
\mathbf{R}\end{array}$ & & & & & $\mathbf{R}$ \\
\hline & $\mathrm{N} 22$ & $\begin{array}{l}1, \mathrm{CC} \\
2, \mathrm{CC}\end{array}$ & $\begin{array}{l}\mathrm{C} \\
\mathrm{C}\end{array}$ & $\begin{array}{l}\text { G } \\
\text { G }\end{array}$ & $\begin{array}{l}\mathrm{F} \\
\mathrm{R}\end{array}$ & R & T & $T$ & & & & & & & $\mathbf{R}$ & & $\begin{array}{l}\mathrm{R} \\
\mathrm{T}\end{array}$ & & & & $\begin{array}{l}\mathrm{R} \\
\mathrm{T}\end{array}$ & \\
\hline & $\mathrm{N} 23$ & $\begin{array}{c}\text { Hole } 572 \mathrm{~A} \\
\text { 1.CC }\end{array}$ & A & G & $\mathbf{F}$ & & $T$ & & & & & & & & $\mathbf{R}$ & & $\mathbf{R}$ & & & & $\mathbf{R}$ & \\
\hline & $\mathrm{N} 22$ & $\begin{array}{l}2, \mathrm{CC} \\
3, \mathrm{CC}\end{array}$ & A & $\begin{array}{l}\mathrm{G} \\
\mathrm{M}\end{array}$ & $\begin{array}{l}\mathrm{F} \\
\mathrm{R}\end{array}$ & & $\begin{array}{l}\mathrm{R} \\
\mathrm{R}\end{array}$ & & $\mathrm{T}$ & & R & & & & & & $\begin{array}{l}\mathbf{R} \\
\mathrm{T}\end{array}$ & $\mathbf{R}$ & & & $\mathbf{T}$ & \\
\hline \multirow[b]{2}{*}{ Pliocene } & $\mathrm{N} 21$ & $\begin{array}{l}4, \mathrm{CC} \\
5, \mathrm{CC}\end{array}$ & $\begin{array}{l}\text { A } \\
\text { C }\end{array}$ & $\begin{array}{l}\mathrm{G} \\
\mathrm{M}\end{array}$ & $\mathrm{R}$ & & R & & & $\mathbf{T}$ & & & & & & & $\mathrm{T}$ & $\mathrm{T}$ & $\begin{array}{l}\mathrm{R} \\
\mathrm{R}\end{array}$ & & & \\
\hline & N19 & $\begin{array}{l}6, \mathrm{CC} \\
7, \mathrm{CC} \\
8, \mathrm{CC} \\
9, \mathrm{CC} \\
10, \mathrm{CC}\end{array}$ & $\begin{array}{l}\mathrm{C} \\
\mathrm{C} \\
\mathrm{C} \\
\mathrm{C} \\
\mathrm{C}\end{array}$ & $\begin{array}{l}\mathrm{M} \\
\mathrm{M} \\
\mathrm{M} \\
\mathrm{M}\end{array}$ & $\begin{array}{l}R \\
R \\
R \\
R \\
T\end{array}$ & & $\begin{array}{l}\mathrm{T} \\
\mathrm{T} \\
\mathrm{R} \\
\mathrm{R} \\
\mathrm{R}\end{array}$ & & & & $R$ & & & $\begin{array}{l}R \\
R \\
T\end{array}$ & & & $\begin{array}{l}\mathrm{R} \\
\mathrm{T} \\
\mathrm{R} \\
\mathrm{T}\end{array}$ & & $\begin{array}{l}\mathbf{R} \\
\mathbf{R} \\
\mathrm{F} \\
\mathrm{R} \\
\mathrm{F}\end{array}$ & $\begin{array}{l}\mathrm{R} \\
\mathrm{R}\end{array}$ & & \\
\hline $\begin{array}{c}\text { late } \\
\text { Miocene }\end{array}$ & $\mathrm{N} 18$ & $\begin{array}{l}11, \mathrm{CC} \\
12, \mathrm{CC} \\
13, \mathrm{CC} \\
14, \mathrm{CC} \\
15, \mathrm{CC} \\
16, \mathrm{CC} \\
17, \mathrm{CC}\end{array}$ & $\begin{array}{l}\mathrm{F} \\
\mathrm{F} \\
\mathrm{F} \\
\mathrm{C} \\
\mathrm{C} \\
\mathrm{C} \\
\mathrm{F}\end{array}$ & $\begin{array}{l}M \\
M \\
M \\
M \\
M \\
M\end{array}$ & $\begin{array}{l}R \\
R \\
T\end{array}$ & & $\mathbf{R}$ & & & & & $T$ & & $\begin{array}{l}R \\
T \\
T \\
R \\
R \\
T\end{array}$ & & . & $\begin{array}{l}R \\
T\end{array}$ & & $\begin{array}{l}\mathrm{R} \\
\mathrm{T} \\
\mathrm{T} \\
\mathrm{T} \\
\mathrm{R}\end{array}$ & & & \\
\hline
\end{tabular}

Note: $\mathrm{G}=\operatorname{good} ; \mathrm{M}=$ moderate; $\mathrm{P}=$ poor. Other symbols as in Table $2 .(\mathrm{L})=$ left coiling; $(\mathrm{R})=$ right coiling.

able. Blow (1969) defined Zone N4 as based on concurrent ranges of Globigerinoides quadrilobatus primordius and Globorotalia kugleri. He believed that the first appearance of the former postdates the first appearance of the latter, thereby enabling two divisions of the range of G. kugleri. Zone N4 of Blow represents the younger part of the range of $G$. kugleri subsequent to the first appearance of Globigerinoides. Since then, many authors (e.g., Stainforth and Lamb, 1981; Srinivasan and Kennett, 1983; Berggren, 1984) have convincingly demonstrated that $G$. quadrilobatus primordius actually evolved earlier than G. kugleri. The usage of Zone N4 in this report is a modified one, defined as the total range zone of G. kugleri. Species of the genus Globigerinoides are susceptible to solution, and little contribution can be made by the Leg 85 sequences regarding the evolutionary development of Globigerinoides in the Oligocene-Miocene interval.

\section{SITE SUMMARIES}

\section{Site 571}

Site 571 is located near the eastern terminus of the equatorial Pacific high-sedimentation belt (Fig. 1). The only core $(7.11 \mathrm{~m})$ taken at this site consists of light, yellow brown, foraminifer-nannofossil ooze. Planktonic foraminifers are generally abundant and well preserved throughout the cored sequence, although we noted faunas affected by marked dissolution at intervals 571-1-1, $140-144 \mathrm{~cm}$ and 1-3, $41-43 \mathrm{~cm}$. Globorotalia menardii is the most dominant element of the planktonic foraminiferal assemblages. Pulleniatina obliquiloculata also commonly occurs in most of the horizons.

In Core 571-1-2, between 119-120 and 131-132 cm, Globoquadrina pseudofoliata becomes extinct. The extinction datum of Globorotalia tosaensis was apparently not reached at this site because assemblages containing this species were not recognized. The paleomagnetically dated deep-sea sequence from the same eastern equatorial Pacific region (Saito et al., 1975; Thompson and Saito, 1977) places the extinction datum levels of Globoquadrina pseudofoliata and Globorotalia tosaensis at 0.22 and $0.60 \mathrm{Ma}$, respectively. Thus, the entire core is assignable to the Brunhes Chron of the paleomagnetic stratigraphy, and the base of the core is no older than $0.6 \mathrm{Ma}$.

\section{Site 572}

This site is nearly due south of Site $\mathbf{5 7 1}$ and is also situated near the eastern edge of the equatorial highproductivity zone. Site 81 of Leg 9 is approximately due east of this site.

Five holes were drilled at Site 572 , yielding $170 \mathrm{~m}$ of a continuously double-piston-cored sequence, and below that, $300 \mathrm{~m}$ of an almost continuously rotary-drilled se- 
Table 3A. (Continued).

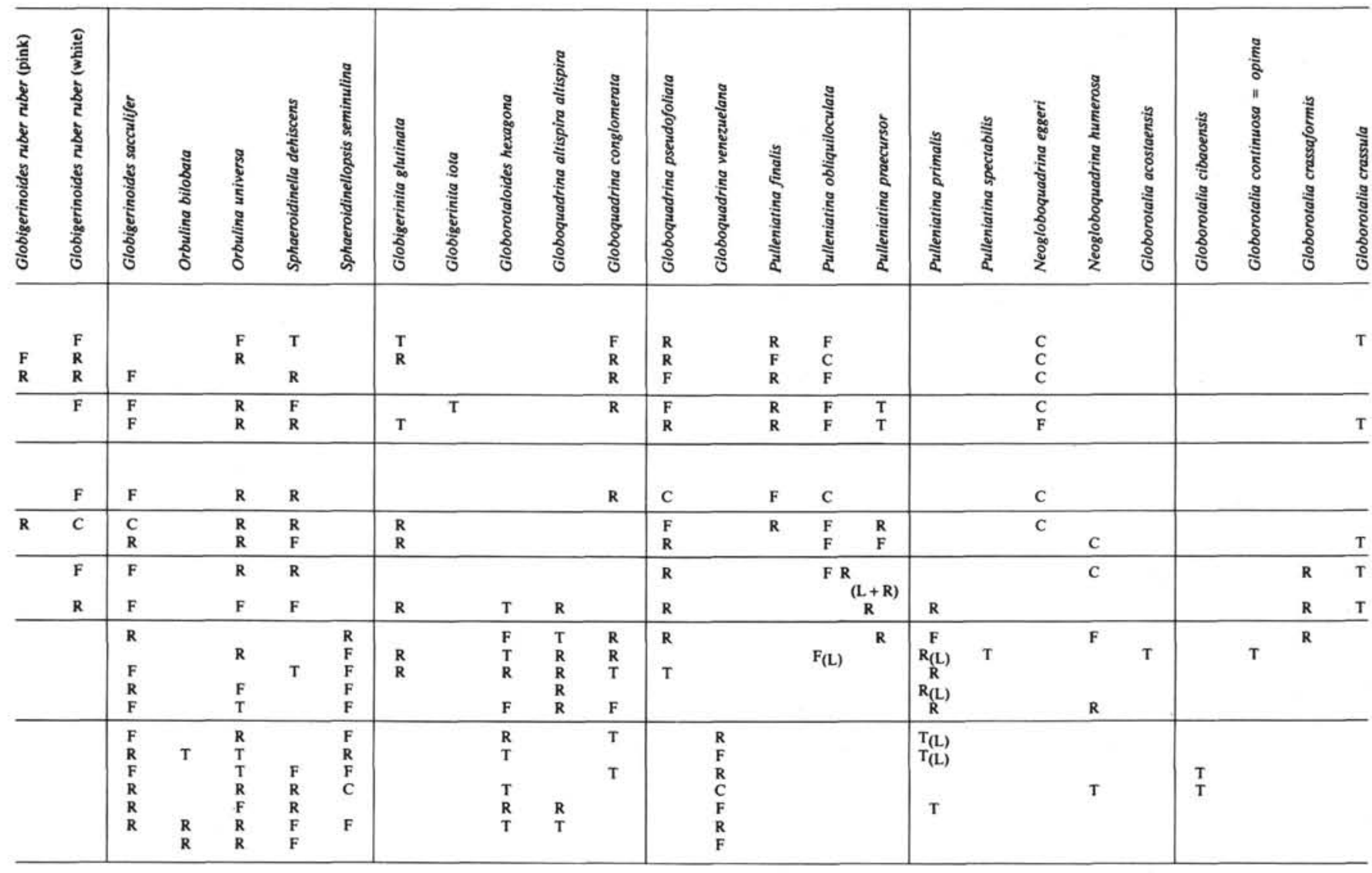

quence. A sediment/basalt basement contact was reached at $479.5 \mathrm{~m}$ in Hole $572 \mathrm{D}$.

Hole $572 \mathrm{~A}$ was continuously piston cored to a subbottom depth of $154 \mathrm{~m}$. Hole 572B was washed down to $154 \mathrm{~m}$, and coring began from that level to $172.1 \mathrm{~m}$ subbottom. Hole $572 \mathrm{C}$ duplicated $572 \mathrm{~A}$, yielding a continuously piston-cored sequence from the mudline to $168.5 \mathrm{~m}$ sub-bottom. Hole 572D was rotary drilled to the basalt basement after washing down to $151 \mathrm{~m}$ sub-bottom.

The state of preservation of planktonic foraminifers makes it possible to divide the 170-m-thick piston-cored sequence into two units. The upper unit, from Cores 1 through 17 in both Holes 572A and 572C, contains abundant and well-preserved assemblages, whereas the lower unit yields moderately well-preserved, but rather monotonous, assemblages. These monotonous assemblages consist largely of such solution-resistant forms as robust Globoquadrina, keeled Globorotalia, and cortex-covered sphaeroidineliids. The downhole change from the upper, rich assemblages to the lower solution-affected assemblages is sharp and occurs between Cores 572C-17 and -18. Planktonic species are practically absent in Sample $572-19$, CC. The upper foraminifer-rich sequence can be correlated precisely with the paleomagnetically dated deep-sea sequence to the west of this site in the equatorial Pacific (Hays et al., 1969; Saito et al., 1975). Such a correlation places the base of the Quaternary, as marked by the extinction of Globigerinoides obliquus, between Samples 2,CC and 3,CC in both Holes 572A and C.
The disappearance of Sphaeroidinellopsis seminulina in Hole 572C between Samples 6-4, 50-52 cm and 6-5, $100-102 \mathrm{~cm}$ is used to draw the upper limit of Zone N19.

Since systematic changes with time in the coiling direction of Pulleniatina have been shown to provide useful datum levels for inter-regional correlation, we plotted coiling direction patterns in assemblages from Holes 572C and 573. The sharp left-to-right coiling direction change, termed L9 by Saito (1976) and known to occur shortly after the Cochiti Subchron of the Gilbert Reversed Chron $(\sim 3.6 \mathrm{Ma})$, occurs in the upper part of Core 572C-7 (Fig. 2).

Although dissolution of foraminifers becomes increasingly evident downsection starting from Core 10 of both Holes 572A and 572C, the first appearance of Globorotalia tumida accompanied by the extinction of Globoquadrina dehiscens between Samples 13,CC and 14,CC enables the placement of the Pliocene/Miocene boundary at this level.

The rotary-cored sequence of Hole 572D yields moderately well-preserved but impoverished middle and upper Miocene foraminiferal assemblages. The effect of dissolution makes it difficult to establish time-rock divisions for this hole based solely on planktonic foraminifers. Two intervals of marked dissolution characterize the middle of the cored sequence (Cores 572D-2 to -8 and -11 to -18 ), whereas a well-preserved and diverse assemblage is present toward the basement in Cores 572D30 through -33. The basal sediment of this hole, Sample 
Table 3A. (Continued).

\begin{tabular}{|c|c|c|c|c|c|c|c|c|c|c|c|c|c|c|c|c|c|c|c|c|}
\hline Age & Zone & $\begin{array}{c}\text { Sample } \\
\text { (interval in } \mathrm{cm} \text { ) }\end{array}$ & 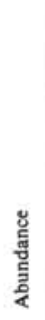 & 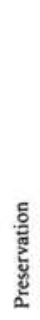 & 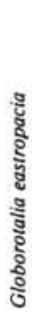 & 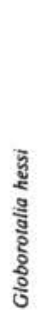 & 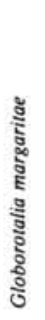 & 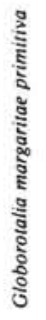 & 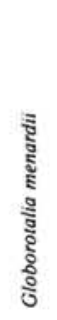 & 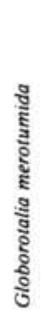 & 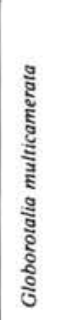 & 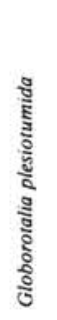 & 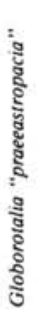 & 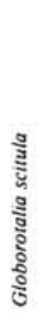 & 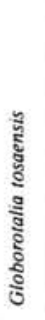 & 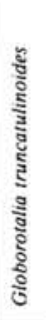 & 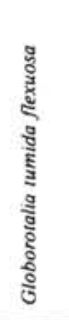 & 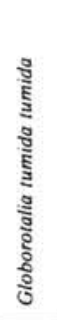 & 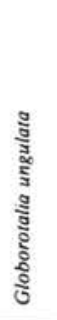 & 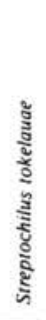 \\
\hline \multirow{4}{*}{ Quaternary } & $\mathrm{N} 23$ & $\begin{array}{l}\text { Hole } 572 \\
\quad \begin{array}{l}1-1,2-5 \\
1-1,14-149 \\
1-2,147-149\end{array}\end{array}$ & $\begin{array}{l}\text { A } \\
\text { C } \\
\text { C }\end{array}$ & $\begin{array}{l}\mathrm{G} \\
\mathrm{G} \\
\mathrm{M}\end{array}$ & $T$ & & & & c & & & & & & & & T & $\begin{array}{l}\mathrm{R} \\
\mathrm{C}\end{array}$ & $\begin{array}{l}R \\
R\end{array}$ & \\
\hline & $\mathrm{N} 22$ & $\begin{array}{l}1, \mathrm{CC} \\
2, \mathrm{CC}\end{array}$ & $\begin{array}{l}\mathrm{C} \\
\mathrm{C}\end{array}$ & $\begin{array}{l}\text { G } \\
\text { G }\end{array}$ & & $\begin{array}{l}\mathrm{F} \\
\mathrm{R}\end{array}$ & & & $\begin{array}{l}\mathrm{F} \\
\mathrm{R}\end{array}$ & & & & & & $\begin{array}{l}\mathrm{R} \\
\mathrm{R}\end{array}$ & $\mathrm{T}$ & & $\begin{array}{l}\mathrm{F} \\
\mathrm{C}\end{array}$ & $\mathrm{T}$ & \\
\hline & $\mathrm{N} 23$ & $\begin{array}{c}\text { Hole 572A } \\
1, \mathrm{CC}\end{array}$ & A & G & & & & & R & & & & & & $\mathrm{R}$ & $F$ & & F & RT & \\
\hline & $\mathrm{N} 22$ & $\begin{array}{l}2, \mathrm{CC} \\
3, \mathrm{CC}\end{array}$ & $\begin{array}{l}\mathrm{A} \\
\mathrm{A}\end{array}$ & $\begin{array}{l}\mathrm{G} \\
\mathrm{M}\end{array}$ & & & & & $F$ & & & & & C & $\mathrm{R}$ & $\mathrm{R}$ & $\begin{array}{l}T \\
T\end{array}$ & $\begin{array}{l}R \\
C\end{array}$ & & \\
\hline \multirow[b]{2}{*}{ Pliocene } & $\mathrm{N} 21$ & $\begin{array}{l}4, \mathrm{CC} \\
5, \mathrm{CC}\end{array}$ & $\begin{array}{l}\text { A } \\
\text { C }\end{array}$ & $\begin{array}{l}\mathrm{G} \\
\mathrm{M}\end{array}$ & & & & & & & c & & & & $R$ & & $\begin{array}{l}\mathrm{R} \\
\mathrm{R}\end{array}$ & $\begin{array}{l}\mathrm{C} \\
\mathrm{C}\end{array}$ & R & \\
\hline & N19 & $\begin{array}{l}6, \mathrm{CC} \\
7, \mathrm{CC} \\
8, \mathrm{CC} \\
9, \mathrm{CC} \\
10, \mathrm{CC}\end{array}$ & $\begin{array}{l}\mathrm{C} \\
\mathrm{c} \\
\mathrm{C} \\
\mathrm{C} \\
\mathrm{C}\end{array}$ & $\begin{array}{l}\mathrm{M} \\
\mathrm{M} \\
\mathrm{M} \\
\mathrm{M}\end{array}$ & & & $T$ & $T$ & $\begin{array}{c}F \\
R_{(L)}\end{array}$ & & $\begin{array}{l}\mathrm{R} \\
\mathrm{R} \\
\end{array}$ & & & $\begin{array}{l}T \\
T \\
T\end{array}$ & & & $\begin{array}{c}R \\
R \\
C \\
F_{(L)} \\
R \\
\end{array}$ & $\begin{array}{l}\mathrm{C} \\
\mathrm{C} \\
\mathrm{C} \\
\mathrm{C} \\
\end{array}$ & & $T$ \\
\hline $\begin{array}{c}\text { late } \\
\text { Miocene }\end{array}$ & $\begin{array}{l}\mathrm{N} 18 \\
\mathrm{~N} 17\end{array}$ & $\begin{array}{l}11, \mathrm{CC} \\
12, \mathrm{CC} \\
13, \mathrm{CC} \\
14, \mathrm{CC} \\
15, \mathrm{CC} \\
16, \mathrm{CC} \\
17, \mathrm{CC}\end{array}$ & $\begin{array}{l}\mathrm{F} \\
\mathrm{F} \\
\mathrm{F} \\
\mathrm{C} \\
\mathrm{C} \\
\mathrm{C} \\
\mathrm{F}\end{array}$ & $\begin{array}{l}\mathrm{M} \\
\mathrm{M} \\
\mathrm{M} \\
\mathrm{M} \\
\mathrm{M} \\
\mathrm{M}\end{array}$ & & & & & $\begin{array}{c}R_{(L)} \\
F \\
R\end{array}$ & $\begin{array}{l}R \\
R \\
T\end{array}$ & & $\begin{array}{c}R \\
T_{(L)} \\
R \\
F \\
T \\
R\end{array}$ & $\mathrm{~T}$ & $\begin{array}{l}T \\
R \\
T\end{array}$ & & & & $F_{(L)}$ & & \\
\hline
\end{tabular}

33, CC, contains rare specimens of Orbulina universa in association with Globorotalia peripheroronda and $G$. praemenardii and is assigned to Zone N9, the lowest middle Miocene zone. Paleontologists on Leg 9 assigned the basal sediment of Hole 81 to the uppermost lower Miocene Zone N8 (Hays et al., 1972). Their zonal assignment was not based on the occurrence of the zonal marker species Globigerinoides bisphericus, but rather on the presence of Hastigerinella bermudezi (referred to as Clavatorella bermudezi in the present report). Since Blow (1969) reported that $H$. bermudezi ranges from the uppermost part of Zone N8 through the lower part of Zone N10, the basal sediment in Hole 81 could well be of Zone N8 age. However, the same Leg 9 report shows the range of $H$. bermudezi in a more continuously cored sequence at Site 77 (about $960 \mathrm{~km}$ due west of Site 572 in the eastern equatorial Pacific) to be restricted to the middle Miocene in zones equivalent to N9 and N10. At Site 572, $H$. bermudezi occurs in association with the Zone N9 assemblage. Therefore, the basal sediment at Site 81 is here reinterpreted to be of Zone N9 age, in agreement with our findings.

\section{Site 573}

This site represents the southernmost of a three-site latitudinal transect along $133^{\circ} \mathrm{W}$ across the equatorial high-productivity belt and was chosen to sample the maximum sediment accumulation along the equator. Coring was also intended to duplicate the well-studied section recovered at Site 77 of Leg 9 (Fig. 1).

The upper $160 \mathrm{~m}$ of the sedimentary column at this site were piston cored in Holes 573 and 573A, and the remaining $370 \mathrm{~m}$ were rotary cored in Hole 573B. Hole $573 \mathrm{~A}$ duplicates the upper $60-\mathrm{m}$ section of Hole 573. Hole 573B penetrated a baked sediment/basalt contact at $528.0 \mathrm{~m}$ sub-bottom. An approximate 1.6 -m-thick Eocene biogenic limestone layer and 3.5-m-thick metalliferous claystone layer overlie the basalt.

The site yielded upper Eocene through Pleistocene planktonic foraminifers in varying abundances. Most of the fossil assemblages exhibit some alteration by dissolution, which caused such solution-resistant forms as keeled Globorotalia, robust Globoquadrina, sphaeroidinellids, and Catapsydrax to be dominant in the faunas. However, all the species present show a good state of preservation throughout the entire sequence. Two intervals, 112 to 186 and 252.5 to $366.5 \mathrm{~m}$ sub-bottom, show a marked decrease in foraminiferal abundance and correspond to those intervals in which diatom and nannofossil data indicate the presence of stratigraphic hiatuses.

Because of the effect of dissolution, many interesting evolutionary lineages of planktonic foraminifers known from the tropical latitudes are not recorded at this site. One exception is the Globorotalia fohsi evolutionary lineage, which occurs in consecutive order from Core 573B11 to -6 . Since the Orbulina datum is not recorded, the 
Table 3B. Occurrence and estimated abundance of planktonic foraminifers, Holes 572C and 572D.

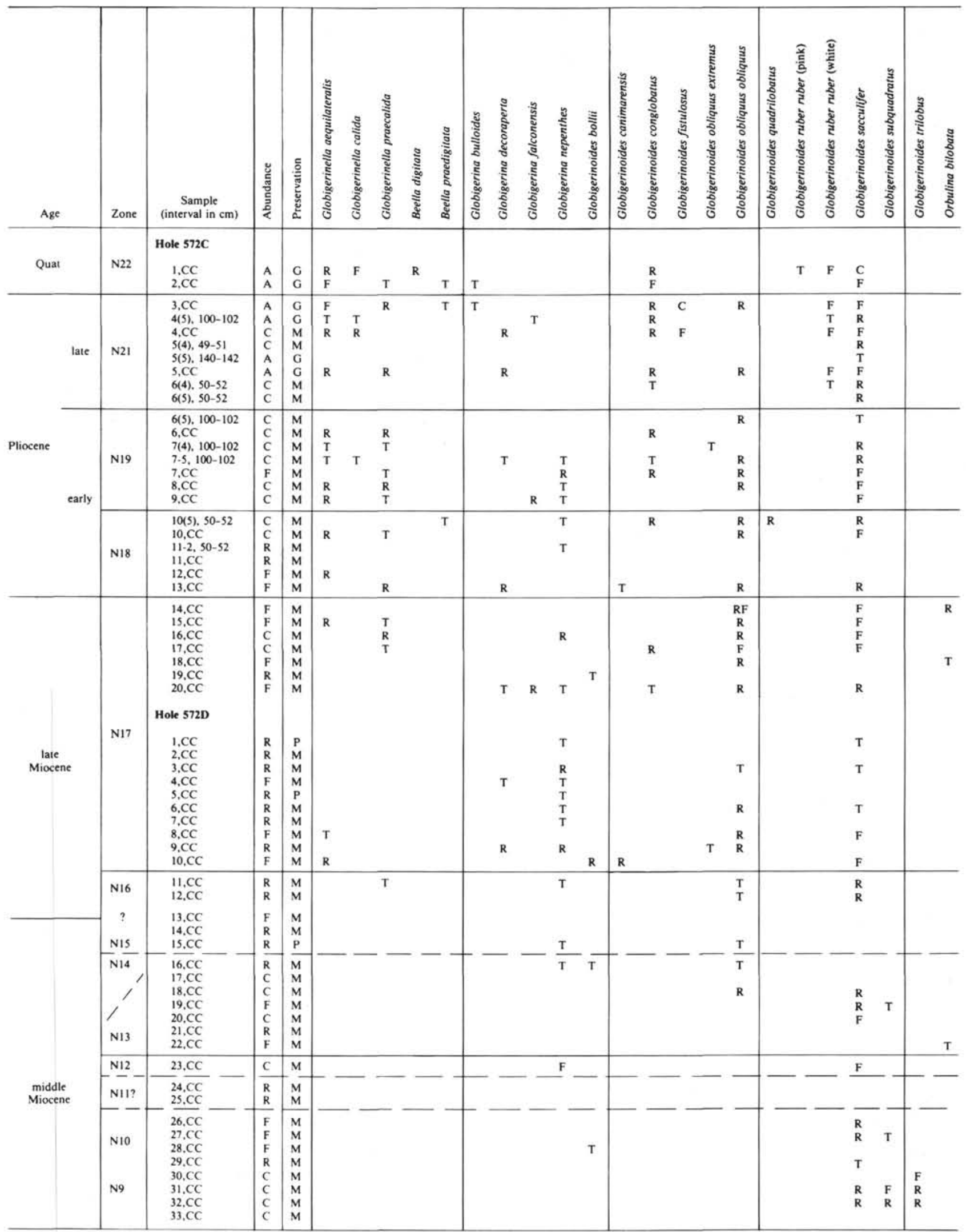

Note: $\mathrm{G}=$ good: $\mathrm{M}=$ moderate; $\mathrm{P}=$ poor. Other symbols as in Table 2. Precise location of diagonal boundary could not be determined. 
Table 3B. (Continued).

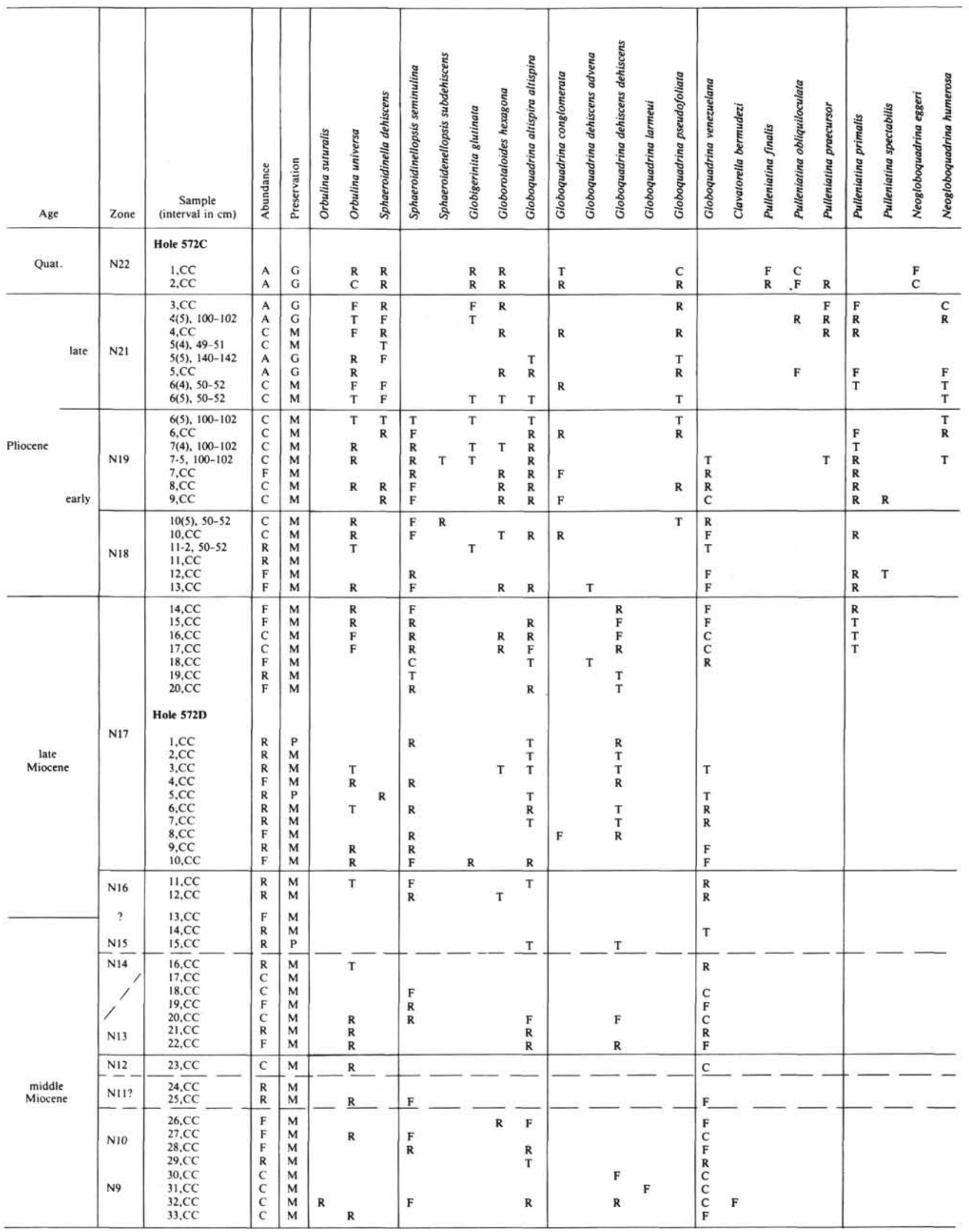


Table 3B. (Continued).

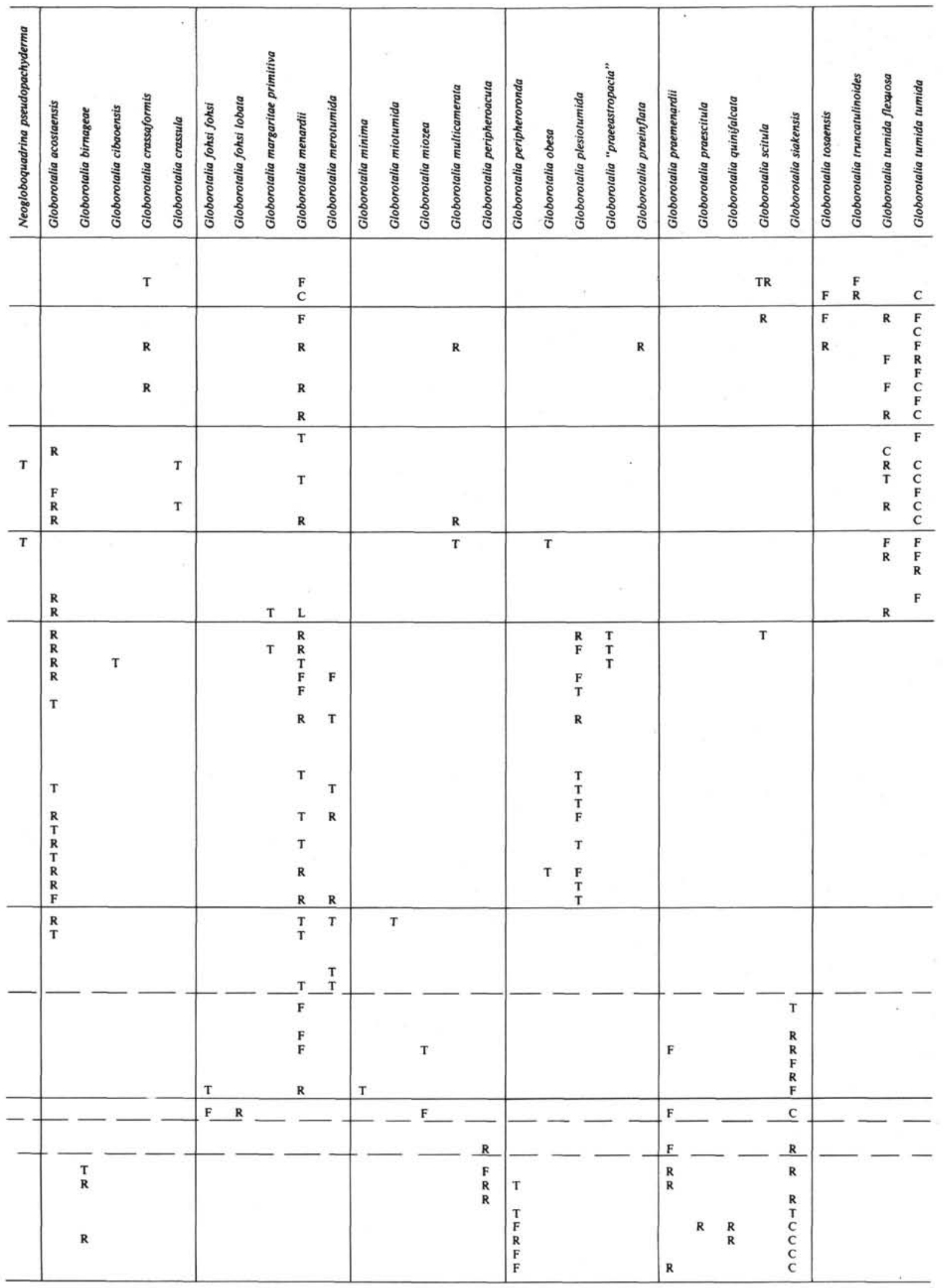


Table 4. Occurrence and estimated abundance of planktonic foraminifers at Site 573.

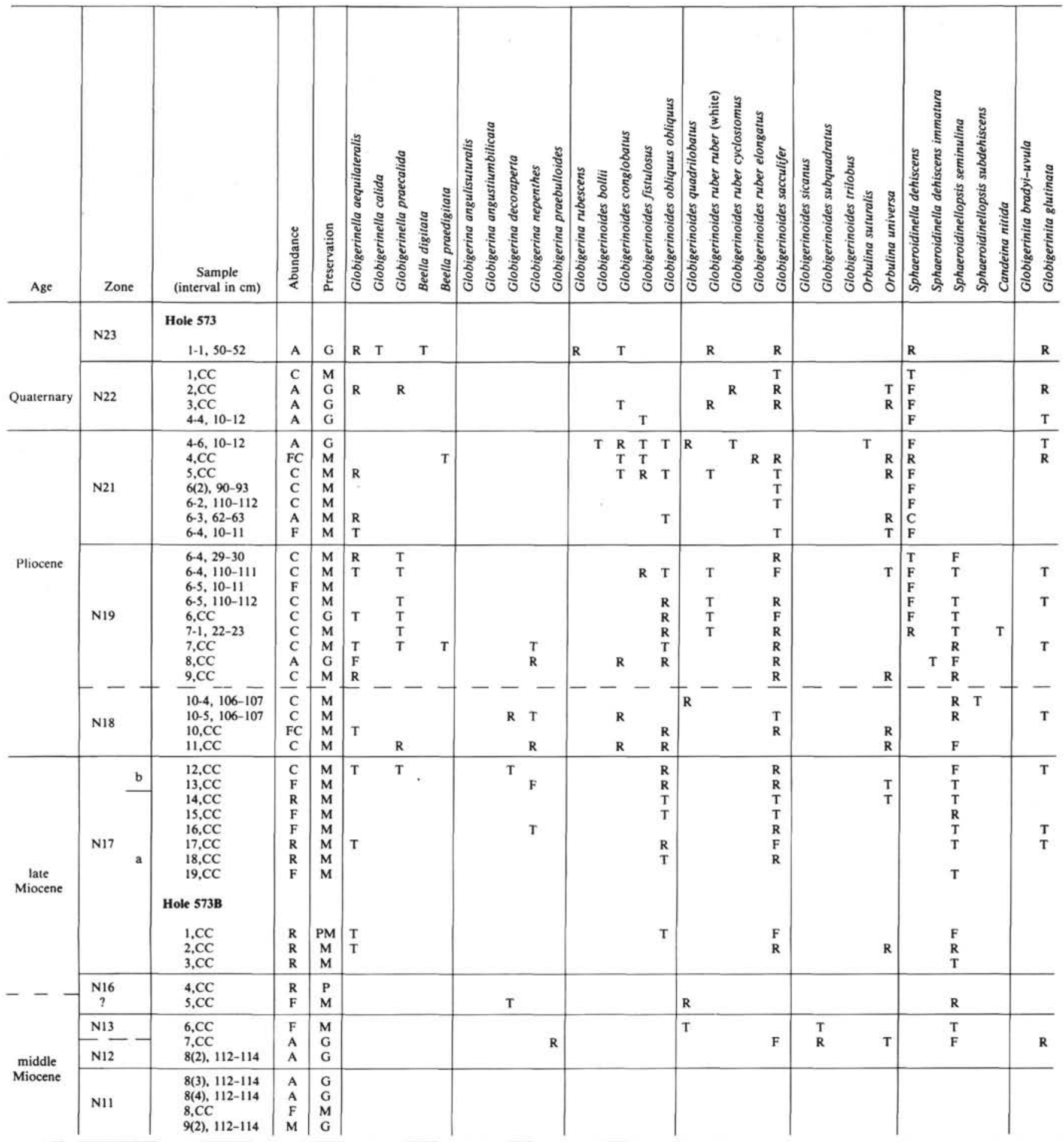

Note: Symbols as in Tables 2 and 3. Species looked for and not found: Globigerina binaiensis, G. bulloides, G. druryi, G. falconensis, G. pachyderma, G. woodi, Globigerinoides canimarensis, G. japonicus, G. obliquus extremus, G. primordius, Praeorbulina glomerosa curva, P. glomerosa glomerosa, Orbulina bilobata, Globigerinita iota, Globegerinatella insueta, Globorotaloides aff. suteri, Globorotalia conomiozea, G. fohsi robusta, G. margaritae primitiva, G. minima, G. miotumida, G. obesa, G. opima continuosa, G. quinifalcata, G. ungulata, Globigerina ciperoensis, G. gortanii, G. tripartita, G. winkleri, Globigerinita africana, Globoquadrina sellii. Globigerinatheka barri, Globigerapsis mexicana, Pseudohastigerina micra, Cribrohantkenina inflata subsp. bermudezi, and Hantkenina primitiva.

a AT.

F-C.
FR.

middle/lower Miocene boundary is approximated at the last appearance level of Globigerinoides sicanus between Samples 573B-12-5, 112-114 cm and -12,CC. The first appearance datum of Globorotalia kugleri is between

Samples 573B-20-4, 110-112 cm and -20-6, 110-112 cm. Since the Oligocene/Miocene boundary is slightly younger than the G. kugleri datum, a possible unconformity, recognized in Core 573B-22 or -21 on the basis of nan- 
Table 4. (Continued).

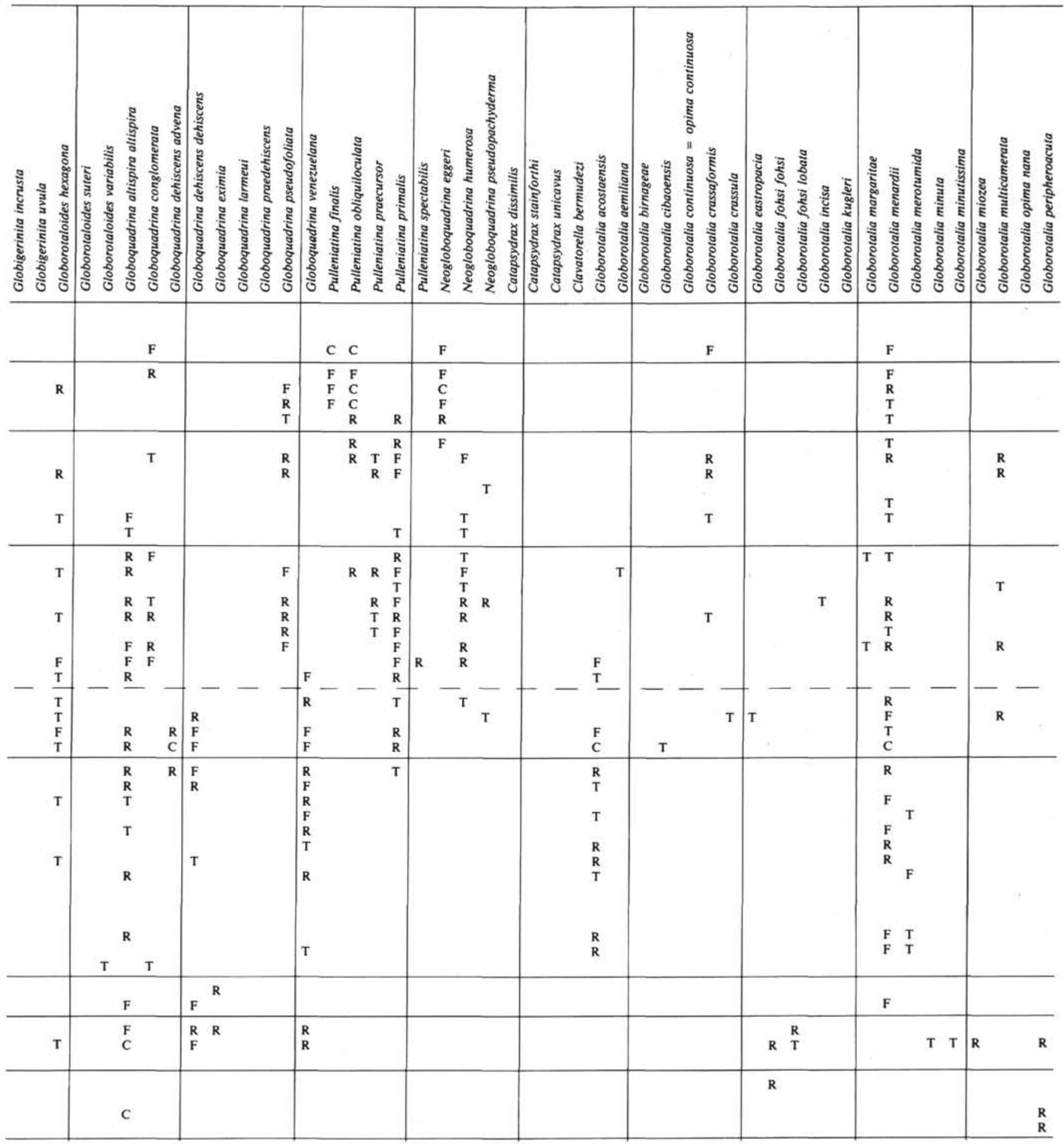

nofossil and radiolarian evidence, must be dated as latest Oligocene.

A surprisingly well-preserved and somewhat diverse upper Eocene planktonic foraminiferal assemblage occurs near the base of the sedimentary column just below the dark brown metalliferous claystone. A few specimens of delicate spine-bearing species such as Hantkenina primitiva and Cribrohantkenina inflata bermudezi are observed in Samples 573B-42-4, 123-124 cm and $140-144 \mathrm{~cm}$. Species belonging to the characteristic Eocene genera Globigerinatheka and Globigerapsis are also present in large numbers. The joint occurrence of $C$. inflata bermudezi and Globigerapsis mexicana is used to establish a late Eocene age (Zone P16). The presence of these varied Eocene assemblages at Site 573 is in marked contrast to the meager fauna reported from nearby Site 
Table 4. (Continued).

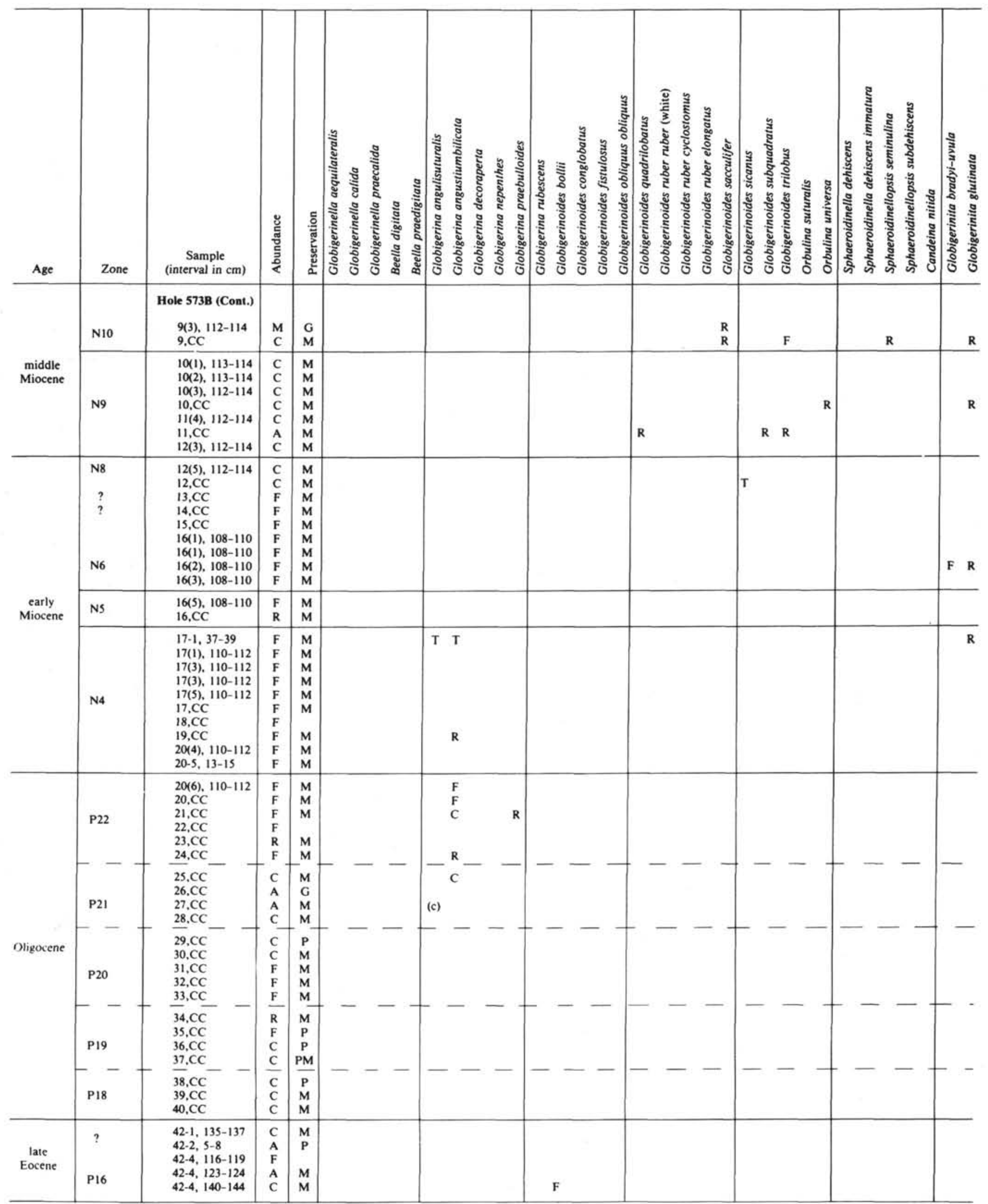


Table 4. (Continued).

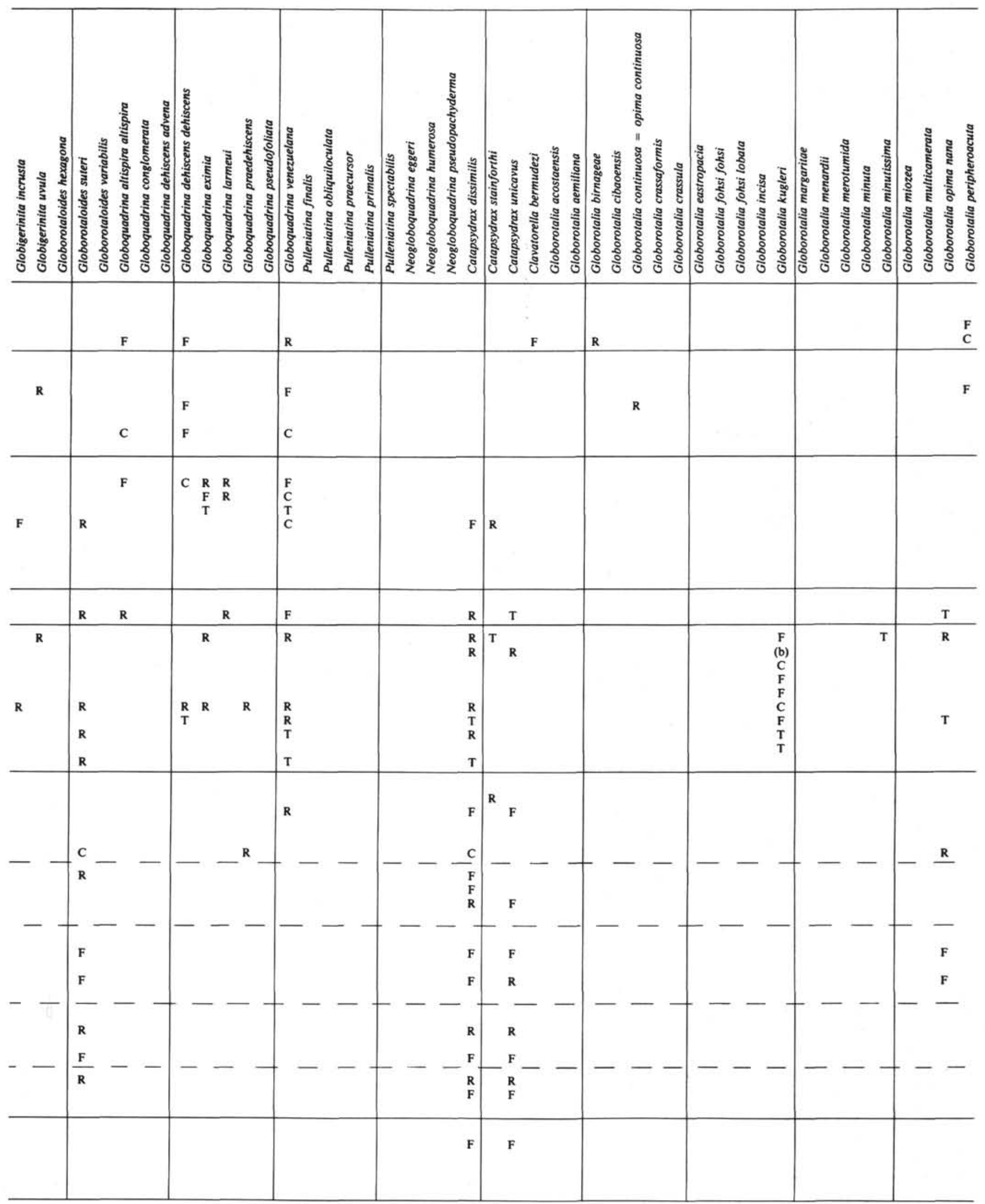


Table 4. (Continued).

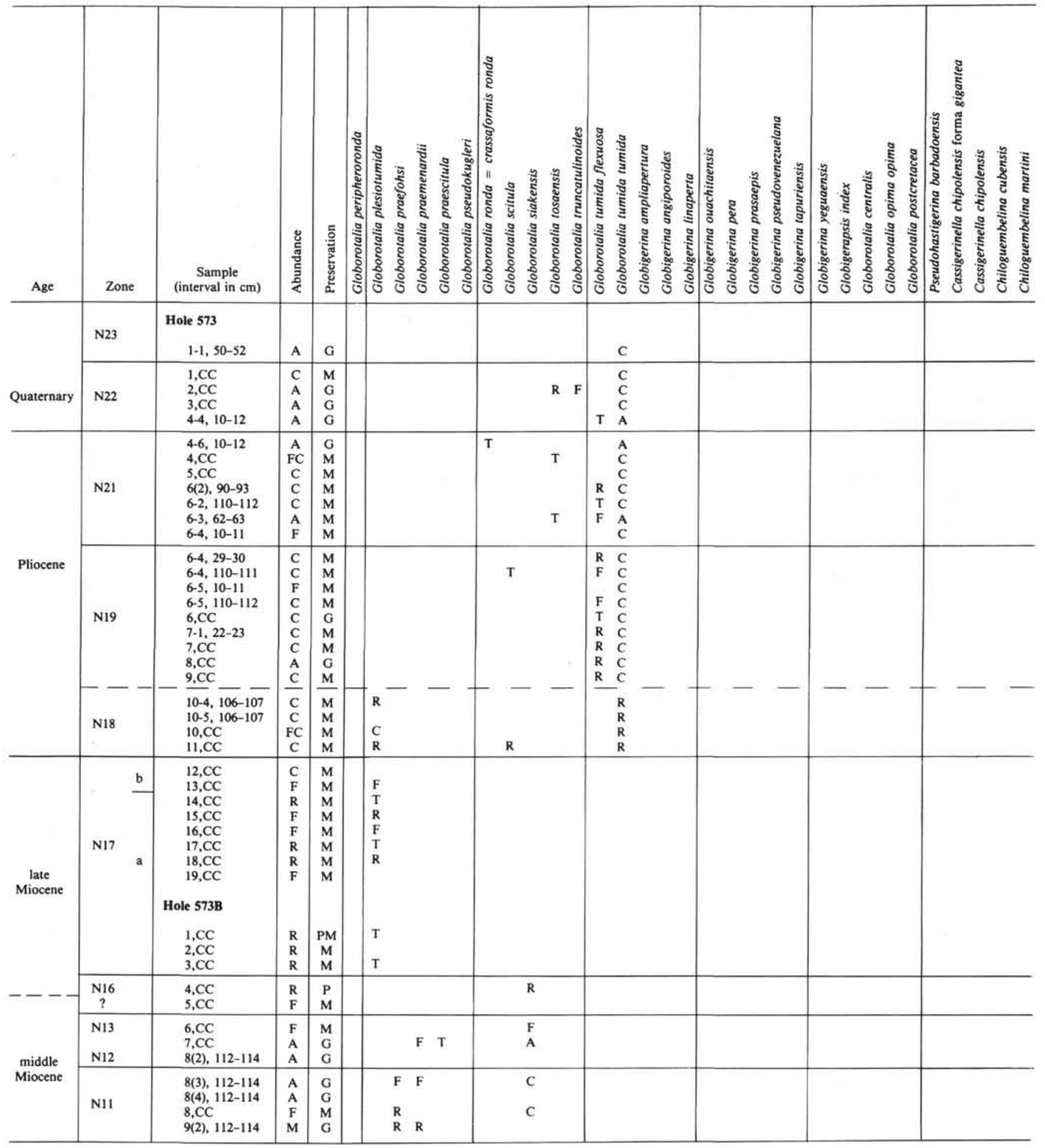

77 , where only one species, $G$. insolita, was found to be diagnostic of a late Eocene age (Jenkins and Orr, 1972). The abundance of Eocene foraminifers diminishes upward as the metalliferous layer is approached, and no foraminifers occur in that layer. Sample 573B-42-2, 48$50 \mathrm{~cm}$, which was taken immediately above the metalliferous layer, contains a rich benthic foraminiferal fauna dominated by calcareous forms, a fauna that suggests severe dissolution of planktonic species at this level. At
$40 \mathrm{~cm}$ above this sample, an Oligocene planktonic assemblage assignable to the upper P18 Zone is present. These observations suggest that the Eocene/Oligocene boundary at Site 573 is marked by a break in the foraminiferal sequence, in which at least the P17 and lower P18 assemblages are not present. Also, just prior to and immediately subsequent to the deposition of the metalliferous layer, some mechanism appears to have dissolved planktonic foraminifers, calcareous nannoplankton, and 
Table 4. (Continued).

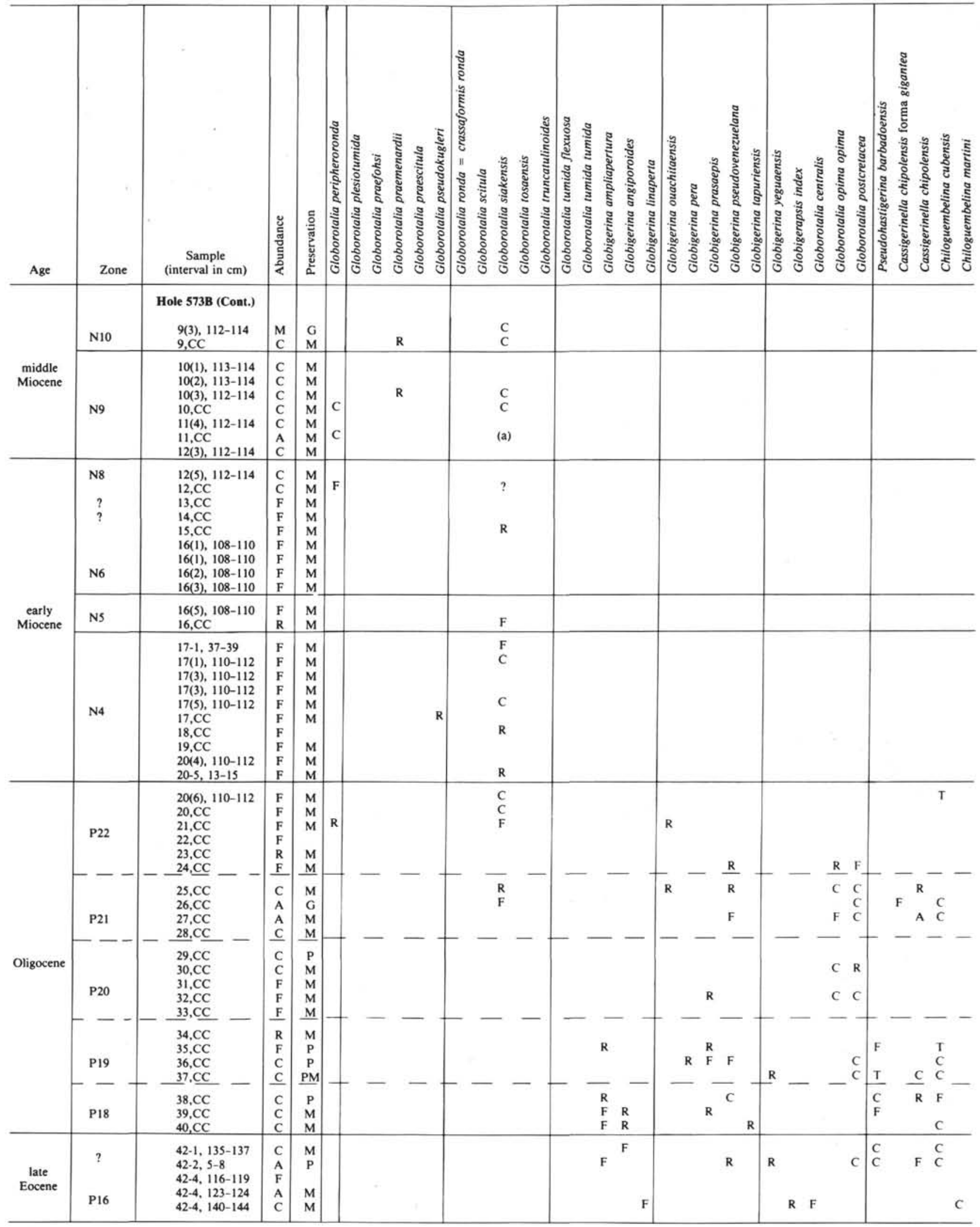


Table 5. Occurrence and estimated abundance of planktonic foraminifers at Site 574.

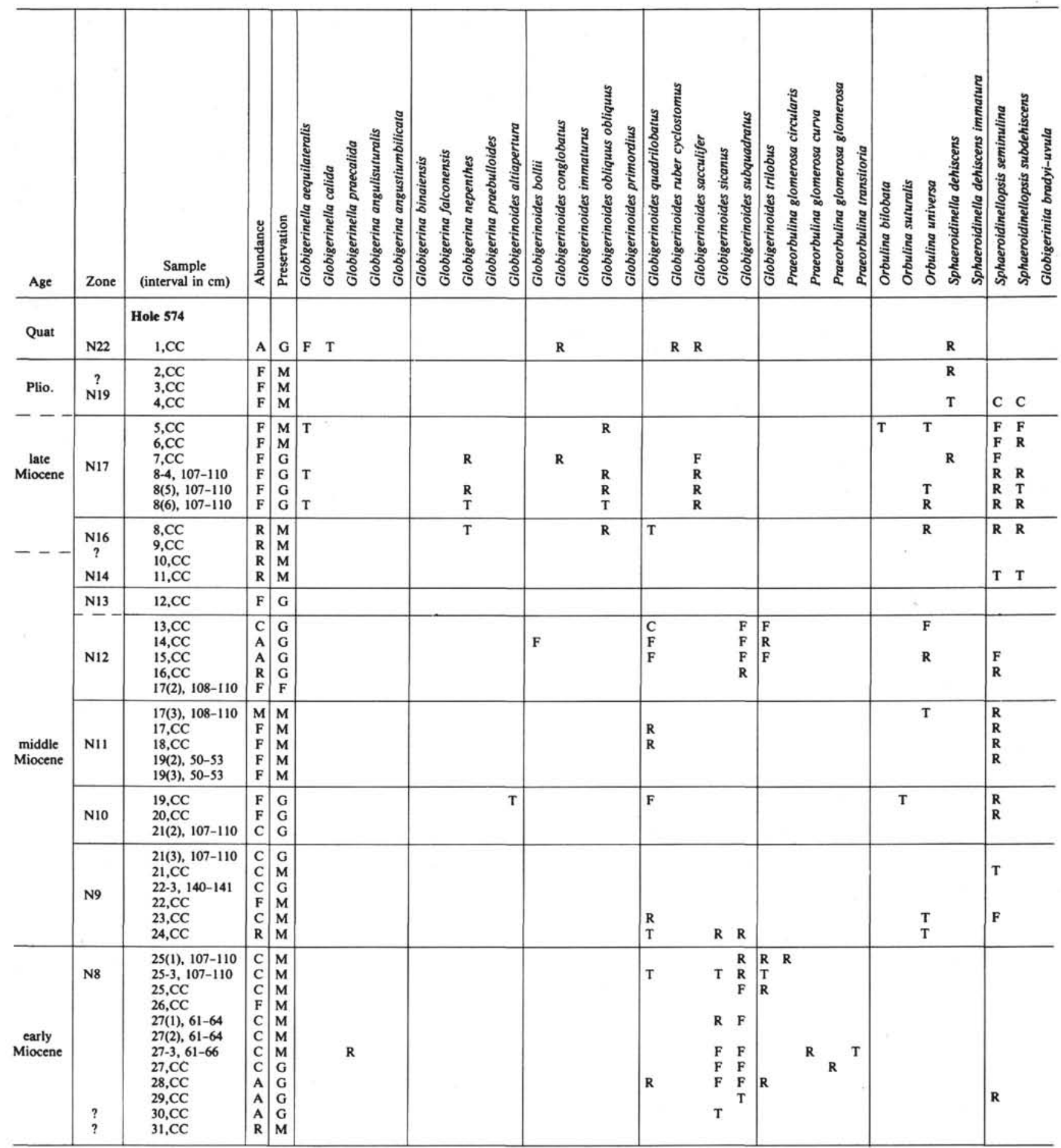

Note: Symbols as in Tables 2 and 3.

some or most of the benthic foraminifers. The metalliferous layer was thus most likely deposited during a time when dissolution was prevalent in the area. Recent studies indicate that ocean ridge-crest hydrothermal activity is responsible for the generation of metalliferous layers (e.g., Edmond et al., 1982). The absence of foraminifers and other microfossils in and around the metalliferous layer could argue for corrosion of biogenic material by a hydrothermal solution.

\section{Site 574}

Site 574 , about $350 \mathrm{~km}$ north of Site 573 , is the second site of the three-site latitudinal transect and is situated just north of the crest of the equatorial sediment belt. Four holes were drilled at this site. The upper $206 \mathrm{~m}$ of sediments were piston cored in a duplicate set in Holes 574 and 574A, and the remaining $224 \mathrm{~m}$ were rotary cored in Hole 574D. Only one rotary-cored se- 
Table 5. (Continued).

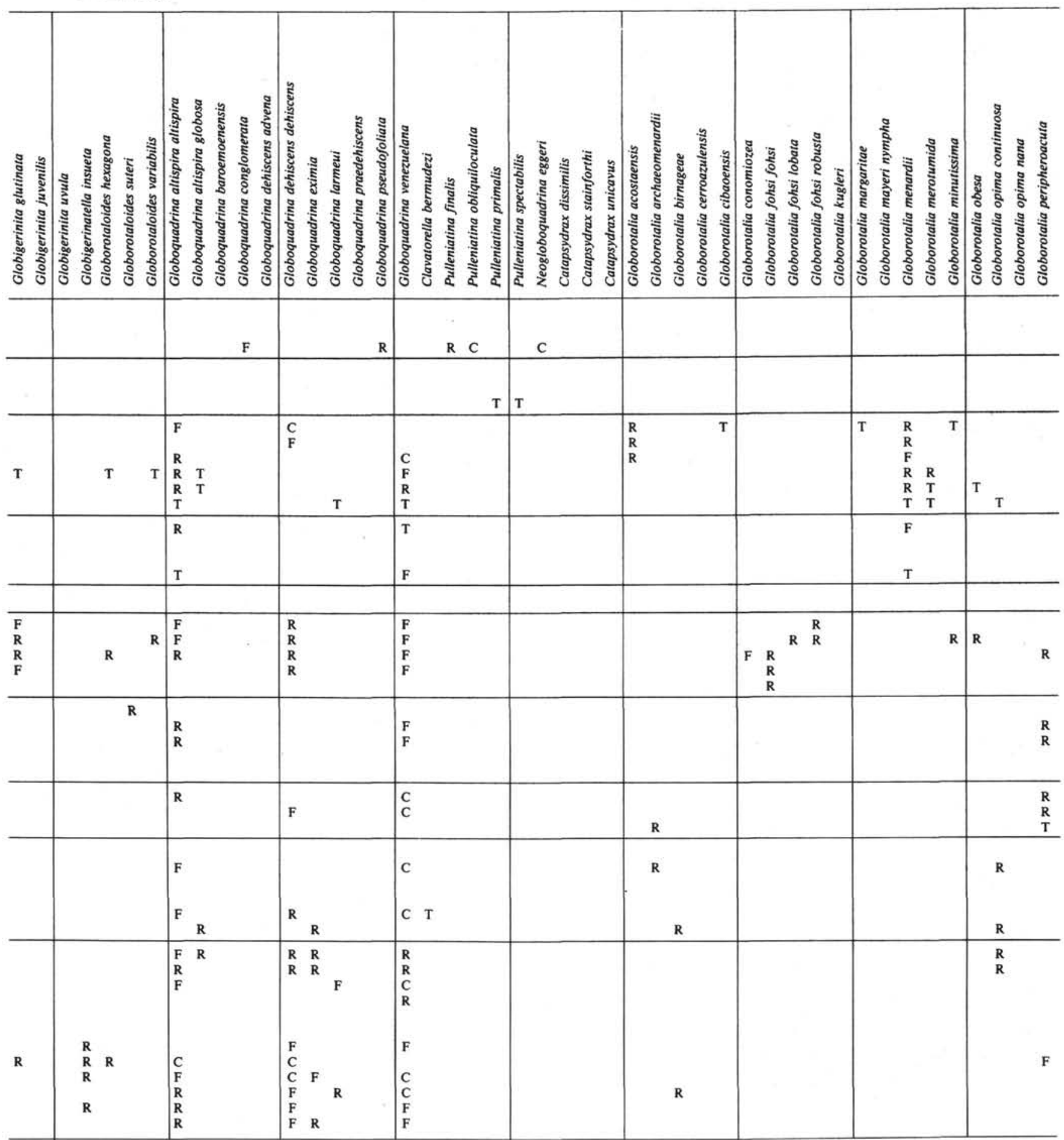

quence was recovered from Hole 574B between 185 and $194.5 \mathrm{~m}$ sub-bottom. Hole 574D ended in basalt at $520 \mathrm{~m}$ sub-bottom.

The recovered sequence yields planktonic foraminiferal faunas from upper Eocene through Pleistocene. Owing to severe dissolution of planktonic foraminifers, however, this fossil group provides good stratigraphic control for only three sections of the sequence, from 110 to $190 \mathrm{~m}$ (Zones N8 through N12), from 230 to $440 \mathrm{~m}$
(Zones N4 through N6), and from $517.5 \mathrm{~m}$ to the base at $520 \mathrm{~m}$ (Zone P17). Other intervals contain rare assemblages; their zonal assignments were established only after consultation with paleontologists studying other microfossil groups.

The sedimentary sequence recovered from the two parallel HPC holes yielded rich and well-preserved assemblages recording two important events in planktonic foraminiferal evolution. One is the well-known "Globoro- 
Table 5. (Continued).

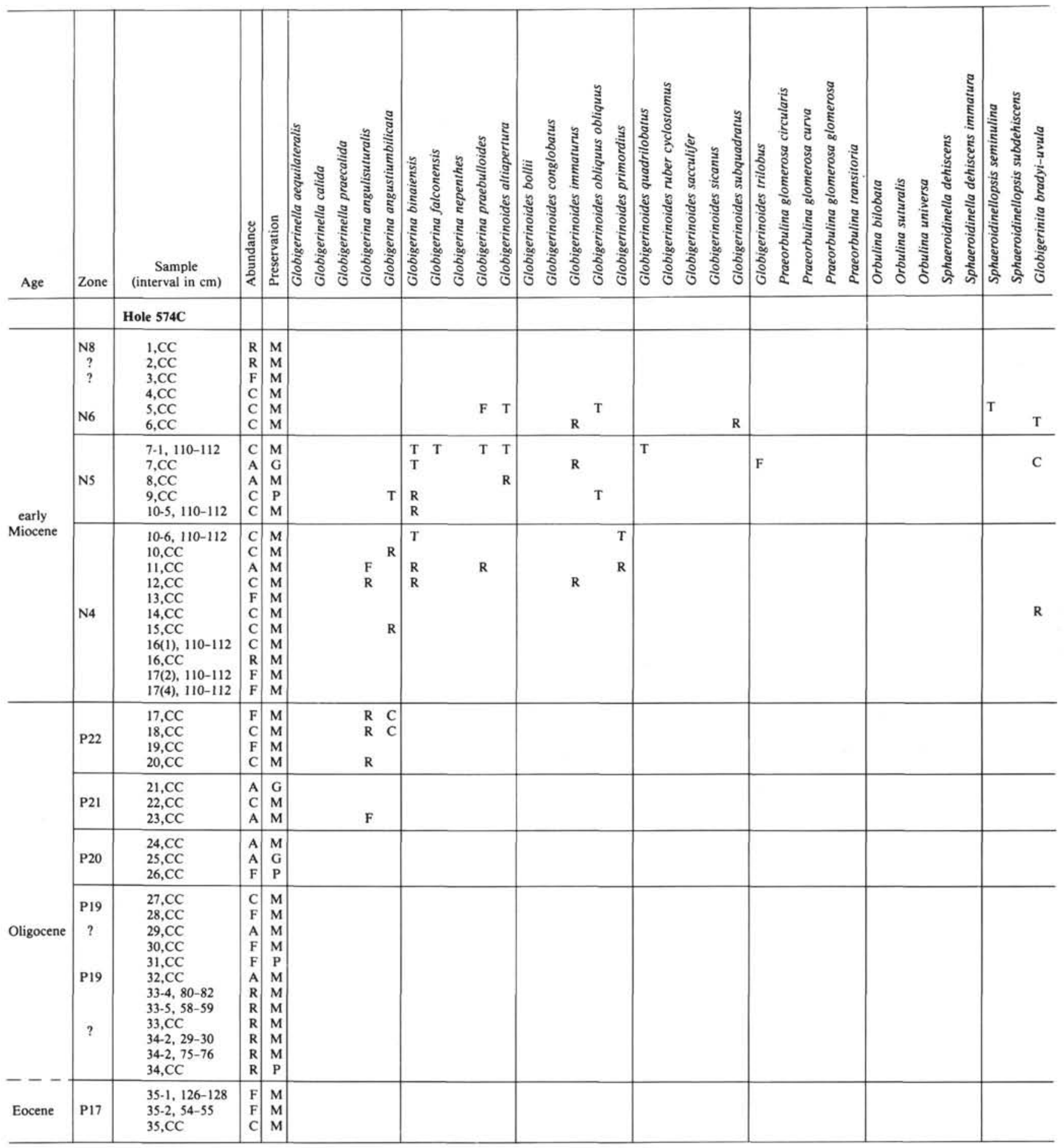

talia fohsi lineage" which underwent rapid development in the tropical region during the early middle Miocene from the small, nonkeeled ancestor $G$. peripheroronda via the medium-sized and weakly keeled $G$. praefohsi to the robust, well-keeled $G$. fohsi robusta (Bolli, 1950; Blow and Banner, 1966). These species are zonal markers for Zones N9 through N12 and provide an excellent means of establishing a precise global correlation. Another event of significant stratigraphic importance is the evolutionary lineage of the genus Orbulina. The first appearance of Orbulina suturalis from its immediate ancestor Praeorbulina occurs at the lower/middle Miocene boundary in the European type section and coincides with the foraminiferal zonal boundary between Zones N8 and N9 (Berggren and Van Couvering, 1974).

The $G$. fohsi evolutionary lineage is traceable in Cores 574-12 through -21 . The Zone N11/N12 boundary is recognized between Samples 17-3, 108-110 cm and 17-2, $108-110 \mathrm{~cm}$; the Zone N10/N11 boundary between 19,CC and 19-3, 50-53 cm; and the Zone N9/N10 boundary 
Table 5. (Continued).

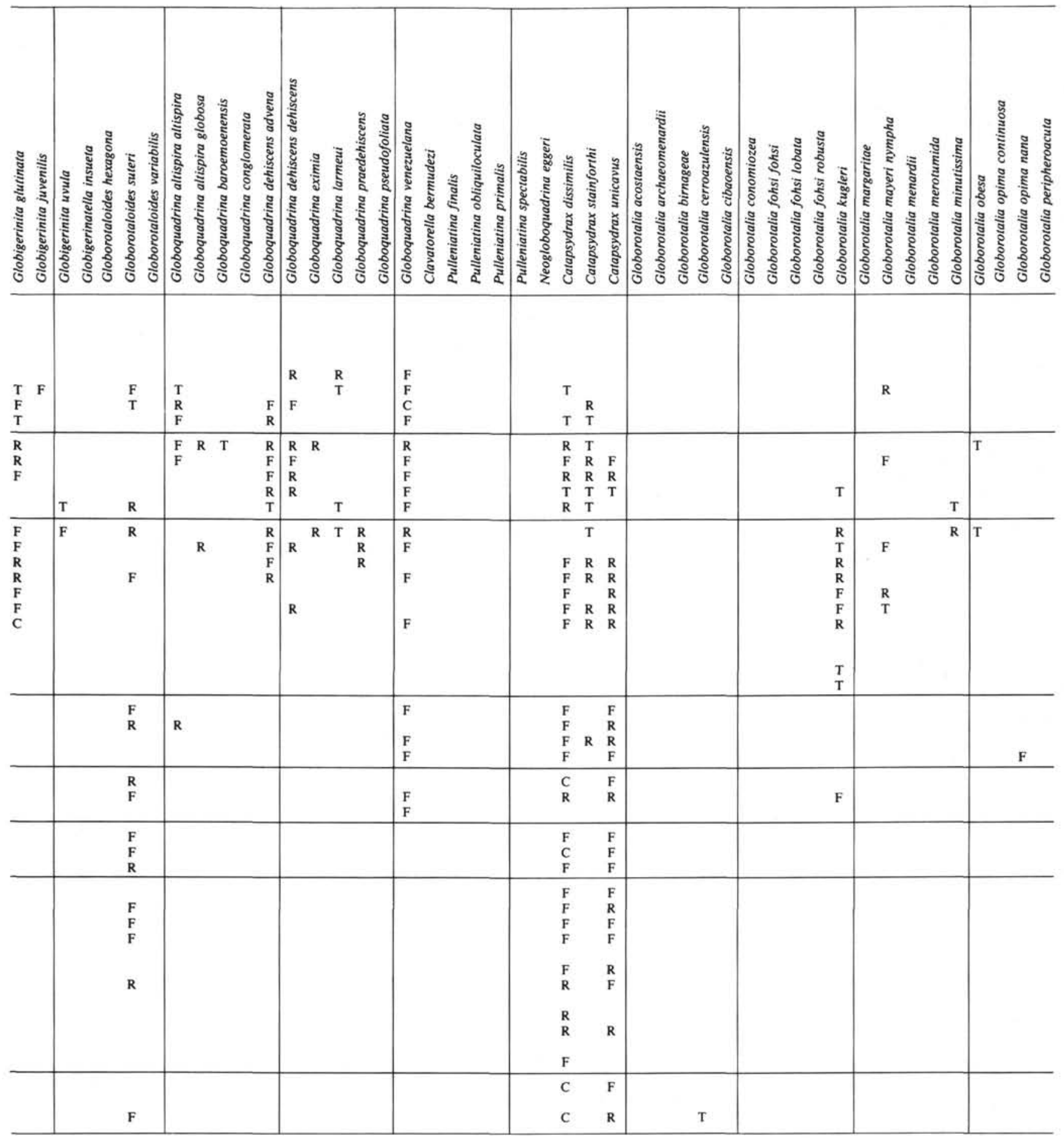

between $21-3,107-110$ and $21-2,107-110 \mathrm{~cm}$. The evolutionary development of the genus Orbulina is recorded in Cores 574-26 and -22. The first appearance datum of Orbulina lies between Samples 574-24,CC and -25-1, $107-110 \mathrm{~cm}$ and Samples 574A-22-6, 144-147 cm and $77-79 \mathrm{~cm}$. At least three sections consisting almost exclusively of reworked Oligocene planktonic foraminiferal faunas occur in the middle Miocene interval: an approximately 9-m-thick section from 574A-17-3, 105-108 $\mathrm{cm}$ to $-18-7,27-29 \mathrm{~cm}$; a 6-m-thick section from 574-21-2,
$138-140 \mathrm{~cm}$ to $-21, \mathrm{CC}$; and a 4-m-thick section from 574A-22-2, 19-20 cm to -22-4, 141-144 cm. A similar section also occurs in the basal part of Core 574-22. Characteristic features common to all of these sections are that (1) the sediment consists predominantly of grains smaller than $150 \mu \mathrm{m}$, and (2) the three species of Oligocene planktonic foraminifers, Chiloguembelina cubensis, Cassigerinella chipolensis, and Globorotalia postcretacea, almost exclusively make up the sediment fraction greater than $63 \mu \mathrm{m}$. Chiloguembelina cubensis somewhat 
Table 5. (Continued).

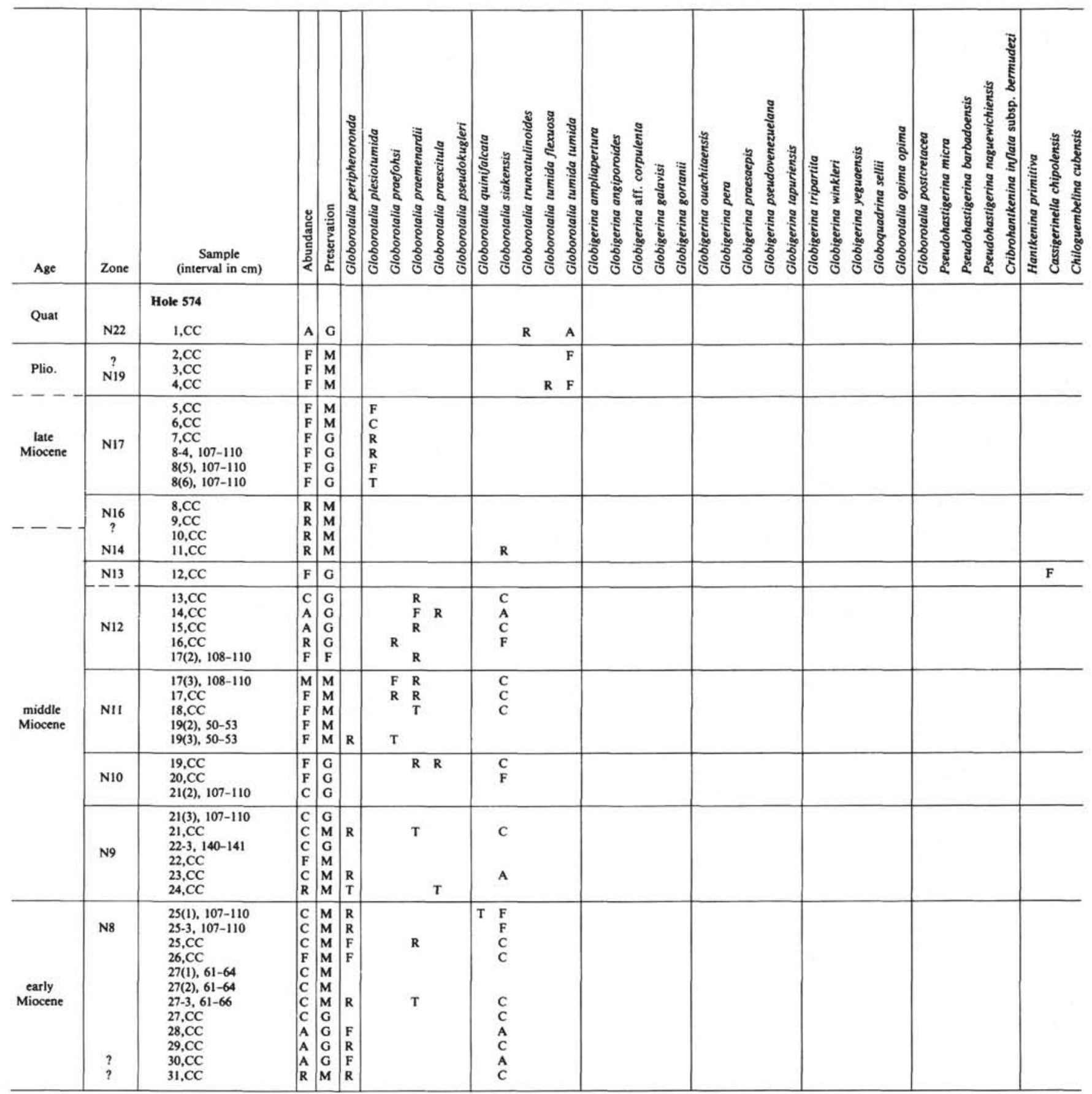

resembles Streptochilus globigera (Schwager), which ranges from middle Miocene to Pliocene. Cassigerinella chipolensis also ranges up to middle Miocene. Thus, an argument could be made that these layers are simply anomalously fine-grained middle Miocene sediments. However, $C$. chipolensis, one of the most easily recognizable species, appears to have become extinct earlier in this part of the Pacific, in early Miocene. Jenkins and Orr (1972, p. 1084), in their study of nearby Site 77 of Leg
9, also described a shortened stratigraphic range of $C$. chipolensis. One plausible explanation for the origin of such homogeneous reworked layers is that an active bottom current winnowed fine carbonate fractions out of some seafloor Oligocene exposures and transported these fine-grained carbonates to the present site as a flocculation load.

The Globorotalia kugleri total range zone, here defined as Zone N4, is unusually thick at this site, span- 
Table 5. (Continued).

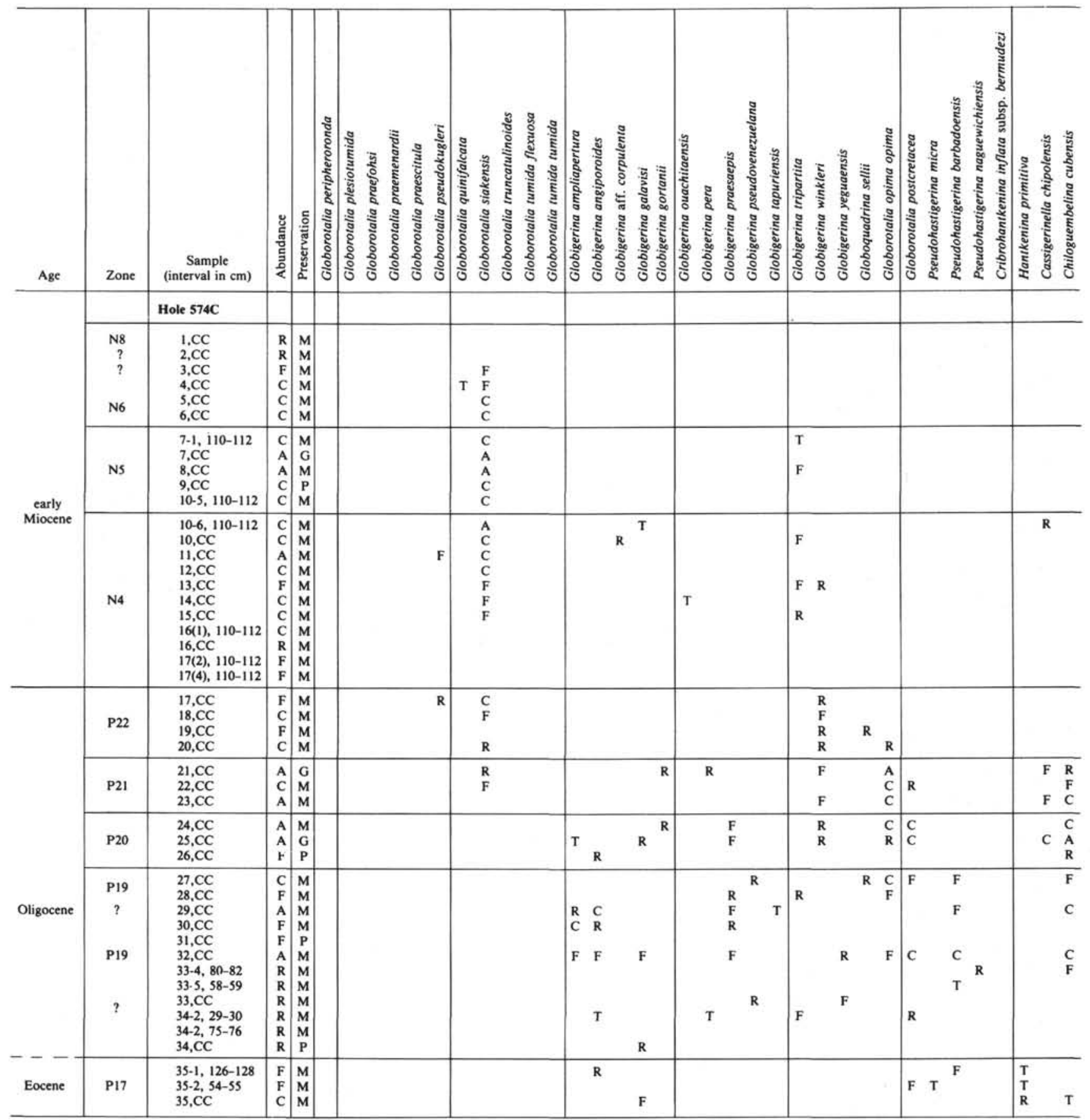

ning eight cores from 574C-17 through -10. Keller (1981a, b) documented similarly expanded sections all over the equatorial Pacific based on her study of Sites 55, 71, 77, and 292. Despite this expanded section of Zone N4, the evolutionary radiation of the genus Globigerinoides cannot be analyzed in detail, because specimens of this genus are almost absent at this site, possibly as the result of dissolution. The first appearance of the genus Globigerinoides had long been thought to mark the Oligocene/Miocene boundary (Berggren, 1972), but it is now considered to have evolved during the late Oligocene. This genus underwent rapid radiation during the early Miocene (Lamb and Stainforth, 1976; Keller, 1980; Srinivasan and Kennett, 1983).

The position of the Oligocene/Miocene boundary in planktonic microfossil sequences has long been debated (see Stainforth and Lamb, 1981; Keller, 1980; Steininger, 1981; Srinivasan and Kennett, 1983). If we accept the Oligocene/Miocene boundary as marked by the initial appearance of Globorotalia kugleri, it would occur be- 
Table 6. Occurrence and estimated abundance of planktonic foraminifers at Site 575.

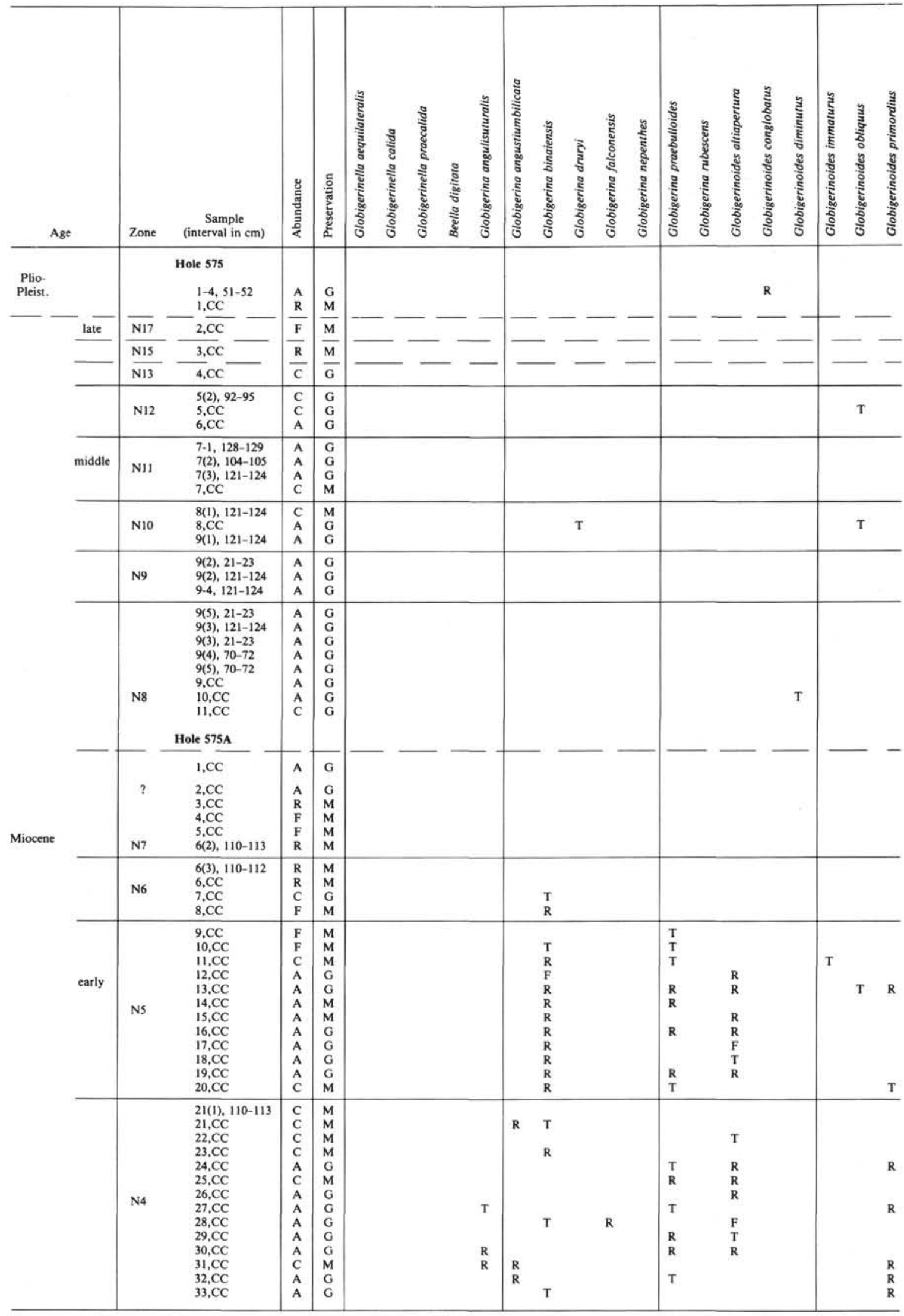

Note: Symbols as in Tables 2 and 3. 
Table 6. (Continued).

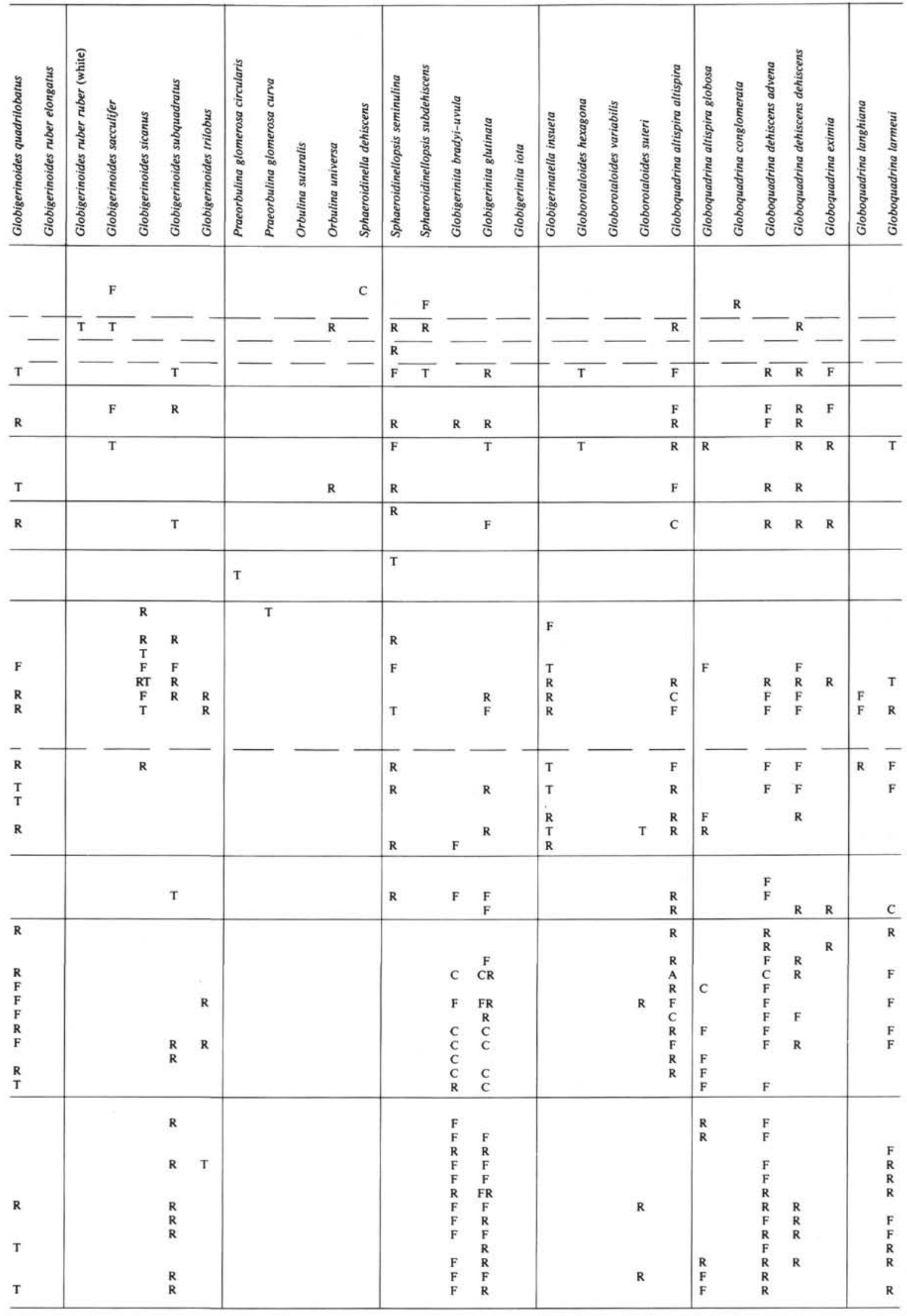


Table 6. (Continued).

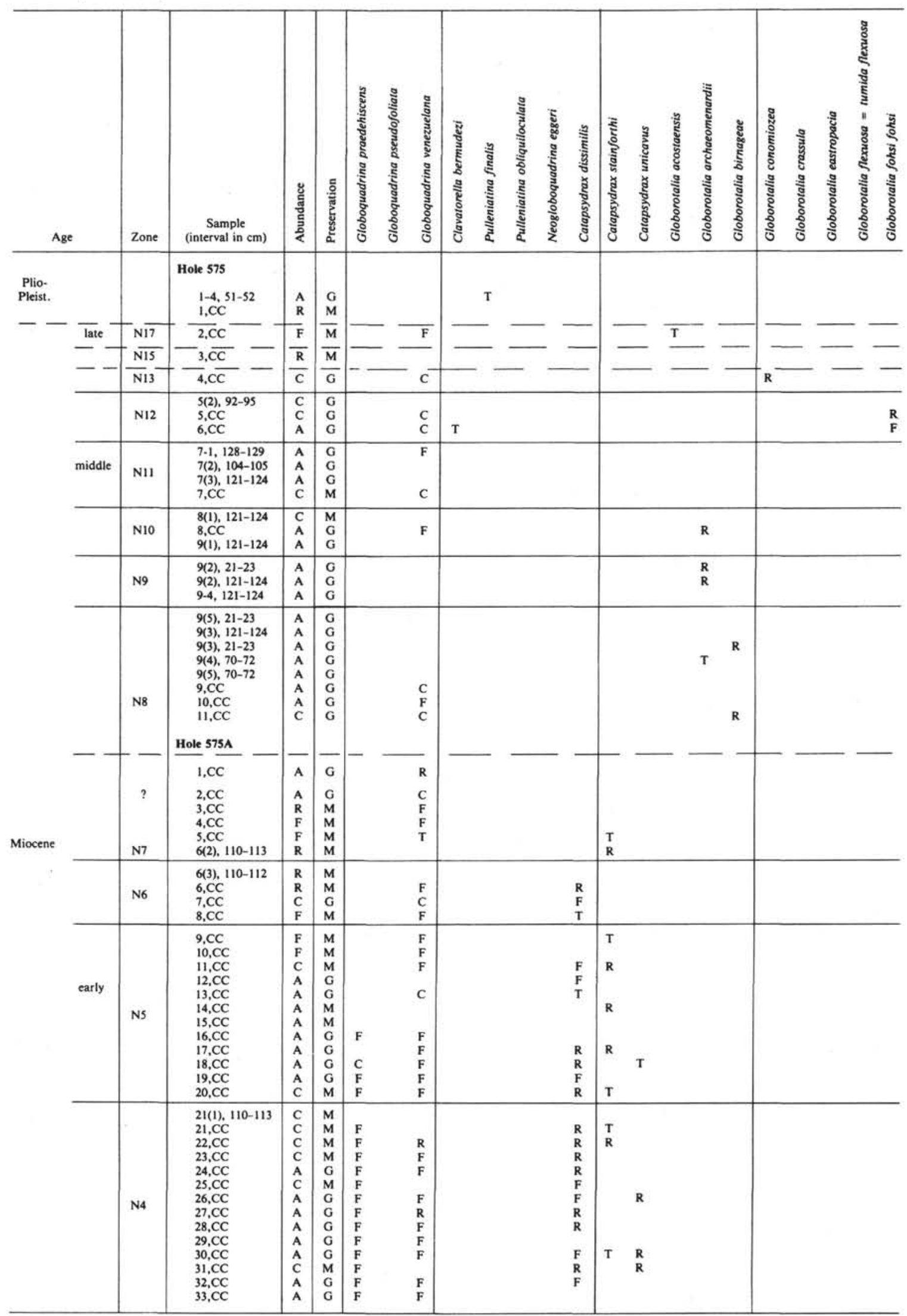


Table 6. (Continued).

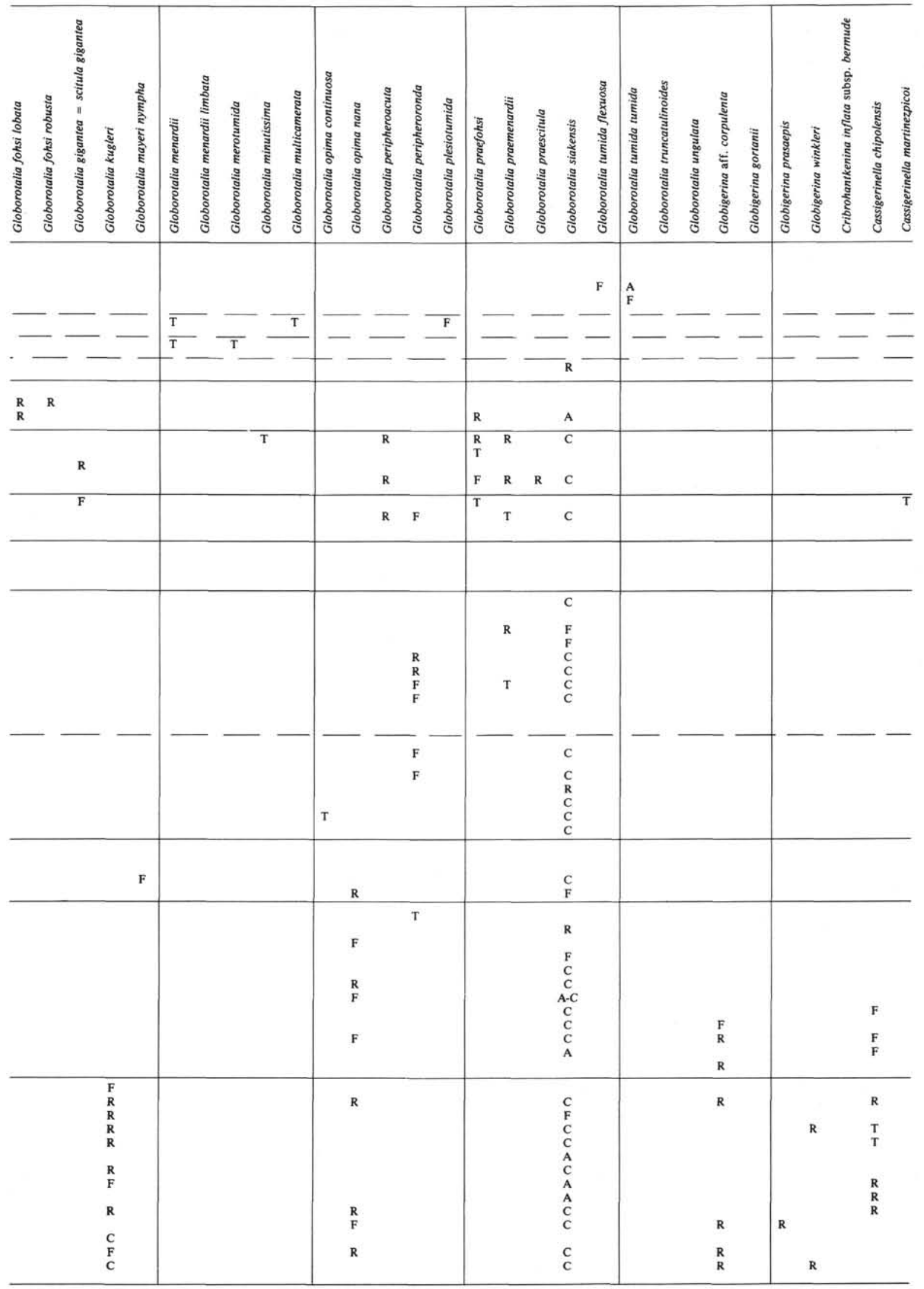




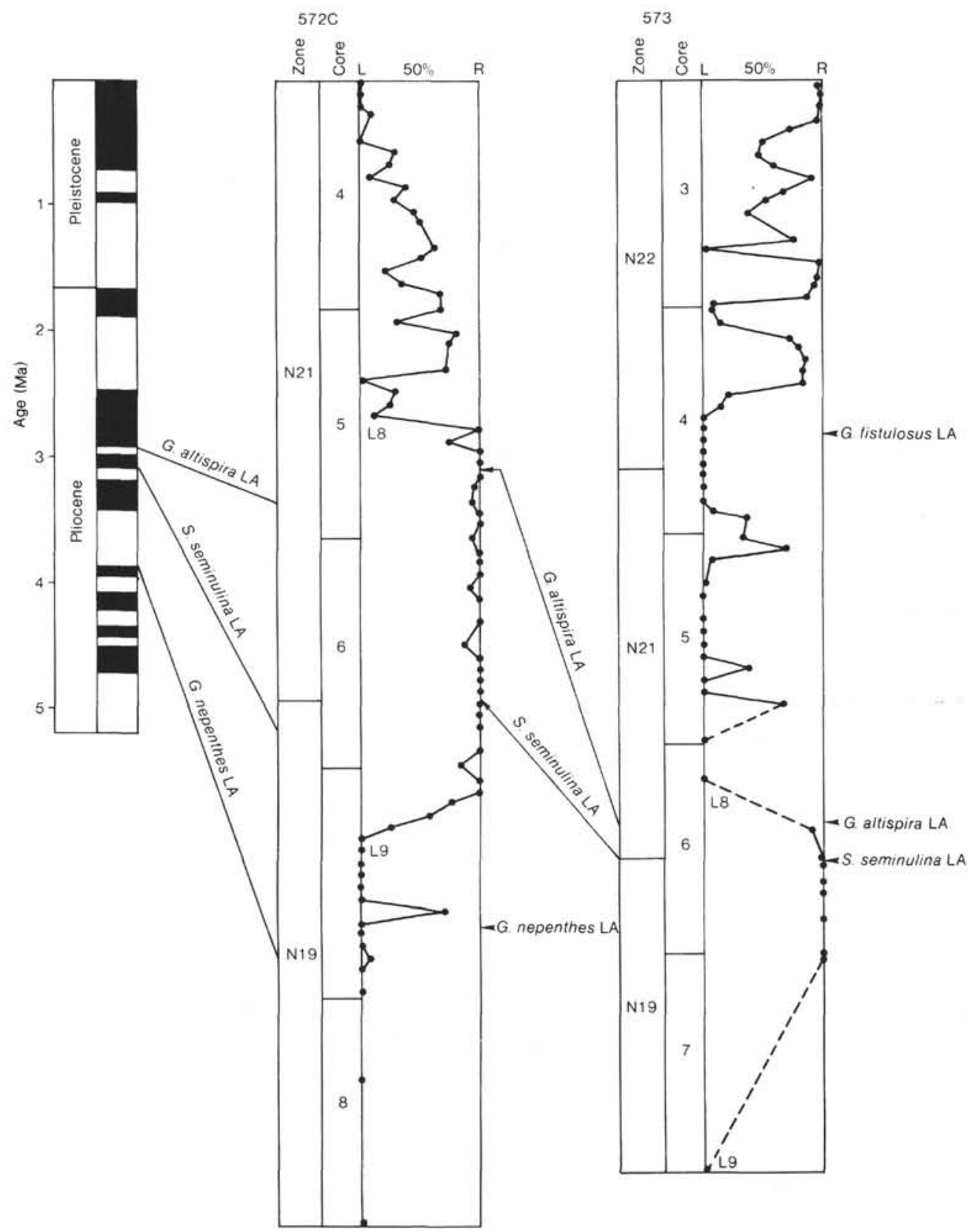

Figure 2. Biostratigraphic correlation of Holes $572 \mathrm{C}$ and 573 based on planktonic foraminiferal datum levels and the preferred direction of coiling in Pulleniatina populations. Correlation of these foraminiferal events with the paleomagnetic stratigraphy is based on Hays et al. (1969) and Saito et al. (1975). L8 and L9 mark the prominent horizons dominated by the left-coiling population of Pulleniatina as established by Saito (1976) in the Gilbert-Gauss (3-5 Ma) interval. Paleomagnetic stratigraphy after LaBrecque et al. (1977). LA = last appearance.

tween Samples 574-17-4, 110-112 cm and -17,CC. However, if we accept Srinivasan and Kennett's (1983) suggestion to draw the boundary below the first appearance level of $G$. dehiscens, it would lie between Samples 574C-14,CC and 574-15, CC.

Downhole encrustation of foraminifers by sediment particles progressively increases in the Oligocene sequence; this state of preservation makes it difficult to establish precise zonal assignments for the Oligocene assemblages. Cores 574-31 through -34 yield sparse assemblages. Moderately well-preserved upper Eocene planktonic for- aminifers occur both in Cores 35-1 and -2. These assemblages include rare specimens of Hantkenina primitiva and Globorotalia cerroazulensis and are assigned to Zone P17 in the uppermost Eocene. The species belonging to the genera Globigerinatheka and Globigerapsis, which characterize the Eocene fauna at Site 573, are not observed at Site 574. Because sediments yielding the Zone P17 fauna underlie a sparsely foraminiferous, metalliferous chalk, the Eocene/Oligocene boundary was not identified on the basis of foraminiferal evidence. Hardenbol and Berggren (1978) regard the extinction level 
of both $H$. primitiva and $G$. cerroazulensis to be one of the criteria that marks the Eocene/Oligocene boundary, and this extinction level occurs between Core 34,CC and $-35-1,126-128 \mathrm{~cm}$. However, dissolution of foraminifers in the metalliferous layer also could have produced the disappearance of these two species.

\section{Site 575}

This northernmost site of the three-site transect is located just south of the Clipperton Fracture Zone. Four HPC holes were drilled at this site. Holes 575 (11 cores, 0 to $98.6 \mathrm{~m}$ sub-bottom), 575B (14 cores, 3.3 to $119.0 \mathrm{~m}$ ), and $575 \mathrm{C}$ ( 2 cores, 0 to $15.8 \mathrm{~m})$ make up a triplicate set representing the upper sedimentary column at this site. Hole $575 \mathrm{~A}$, drilled with a short 3-m core barrel, recovered the lower sedimentary column from 93.8 to $208.4 \mathrm{~m}$ sub-bottom and produced 33 cores. Basement was not reached at this site.

Planktonic foraminifers are abundant to common with good to moderate preservation throughout the cored sequence except for the uppermost $25 \mathrm{~m}$ (Cores 575-1 through -3) and a short section from 102 to $108 \mathrm{~m}$ subbottom (Cores 575A-3 and -4 and 575B-14). The foraminiferal succession is readily zonable from middle Miocene Zone N13 to early Miocene Zone N4, with the exception of the Zone N7/N8 boundary, which falls within an interval affected by intense dissolution.

The two important foraminiferal evolutionary events useful for global stratigraphic correlation, which were recognized at Site 574, were also found at this site. These are the evolutionary lineage of Globorotalia fohsi recorded in Cores 575-4 through -9 and that of the genus Orbulina in Core 575-9. The Zone N12/N13 boundary, which is nearly coincident with the extinction level of the $G$. fohsi lineage, is recognizable between Samples $575-4, \mathrm{CC}$ and $-5-2,94-95 \mathrm{~cm}$. The Zone N11/N12 boundary, as defined by the first appearance of $G$. fohsi sensu lato, occurs between Samples 575-6,CC and -7-1, 128$129 \mathrm{~cm}$. The Zone N10/N11 boundary marked by the evolutionary development of $G$. praefohsi lies between Samples 575-7,CC and $-8-1,121-124 \mathrm{~cm}$ and the N9/ N10 boundary as defined by the first appearance of $G$. peripheroacuta between Samples 575-9-1, 121-124 cm and $-9-2,21-23 \mathrm{~cm}$.

The evolutionary appearance datum of the genus $\mathrm{Or}$ bulina is placed between Samples 575-9-4, 70-72 cm and $-9-5,21-23 \mathrm{~cm}$. The interval from Zones N6 through N8 appears to be greatly condensed, whereas both the overlying Zones N9 through $\mathrm{N} 12$ and the underlying Zones N4 and N5 are much expanded. The deepest sedimentary layer cored at this site is from Zone N4, which is characterized by the common occurrence of G. kugleri.

One of the interesting aspects of the Zone N4 fauna at Sites 574 and 575 is the frequent occurrence of $\mathrm{Globi}$ gerinita uvula (Ehrenberg) and G. glutinata (Egger). Akers and Dorman (1964) included G. naparimaensis Brönnimann, G. incrusta Akers and Tinophodella ambitacrena Loeblich and Tappan in the synonymy of G. glutinata. I consider Globigerina juvenilis Bolli also to be a junior synonym of Globigerinita glutinata, making this species one of the long-ranging planktonic foraminifers in the
Neogene. In the distribution chart of Tables 4 to 7, however, the occurrences of G. glutinata are listed under these separate species names to show the various developmental stages of umbilical bulla and infralaminal openings. Stainforth and Lamb (1981) noted the common occurrence of Globigerinita incrusta $(=G$. glutinata of this chapter) in the G. ciperoensis Zone (=Zone P22) and in the lower half of the Globorotalia kugleri Zone (= Zone $\mathrm{N} 4$ of the present paper). Apparently, little attention has so far been given to the lower stratigraphic range of Globigerinita uvula. In modern oceans, this species is common in temperate and subpolar assemblages. Its small, smooth, high trochospiral test is common to both the modern and early Miocene forms.

Numerous discrete layers of foraminiferal sand, exhibiting a distinct downward increase in grain size, occur throughout the recovered sequence. The turbidite layers present in the uppermost part of the sequence (e.g., Sample $575-1-4,51-52 \mathrm{~cm}$ ) contain a mixed assemblage including taxa indicative of Zones N12 through N17. On the other hand, turbidites in the lower part of the sequence (e.g., Sample 575A-31-3, 70-71 cm) contain a Zone P21 assemblage. In general, reworked assemblages in a given turbidite layer are a few to several zones older than the respective in situ sediments. These turbidites were probably derived from an approximately $1000-\mathrm{m}$ high seamount located $10 \mathrm{~km}$ north of the present site (see Fig. 1 in Site 575 chapter, this volume).

\section{THE ORBULINA DATUM}

The first appearance of Orbulina suturalis Brönnimann has long been recognized as providing a datum level for globally correlating the early/middle Miocene boundary (Van Couvering and Berggren, 1977; Ryan et al., 1974). In the planktonic foraminiferal zonation, this event marks the base of Zone N9 (Blow, 1969; Jenkins et al., 1981). Studies of the European stratotype fauna by Cita and Blow (1969) place this event in the middle part of the Langhian.

However, arguments still continue regarding the calibration of the Orbulina datum with the radiometric time scale and the geomagnetic reversal sequences. This may be partly because only preliminary results of the studies of geomagnetic reversal sequences of the European Neogene stratotype sections have been published (Nakagawa et al., 1974). For instance, age estimates by Berggren and Van Couvering have varied from $18 \mathrm{Ma}$ (Berggren, 1969) to $16 \mathrm{Ma}$ (Van Couvering, 1972; Berggren, 1972) and $14 \mathrm{Ma}$ (Van Couvering and Berggren, 1974). A later paper (Van Couvering and Berggren, 1977), however, advocates the date of $15 \mathrm{Ma}$ based on several lines of evidence, the most important of which are the following: (1) radiometric dating by Page and McDougall (1970) using $\mathrm{K} / \mathrm{Ar}$ on a volcanic sequence in New Guinea above the Orbulina datum gives a 13- to 15-Ma range; (2) similar dating of Japanese volcanic rocks bracketing the $\mathrm{Or}$ bulina datum gives a number of consistent ages of 14 to $16 \mathrm{Ma}$; and (3) Opdyke et al. (1974) and Theyer and Hammond (1974) come to a close agreement with an age of $15 \mathrm{Ma}$ for levels very close to the Orbulina datum in deep-sea cores. 


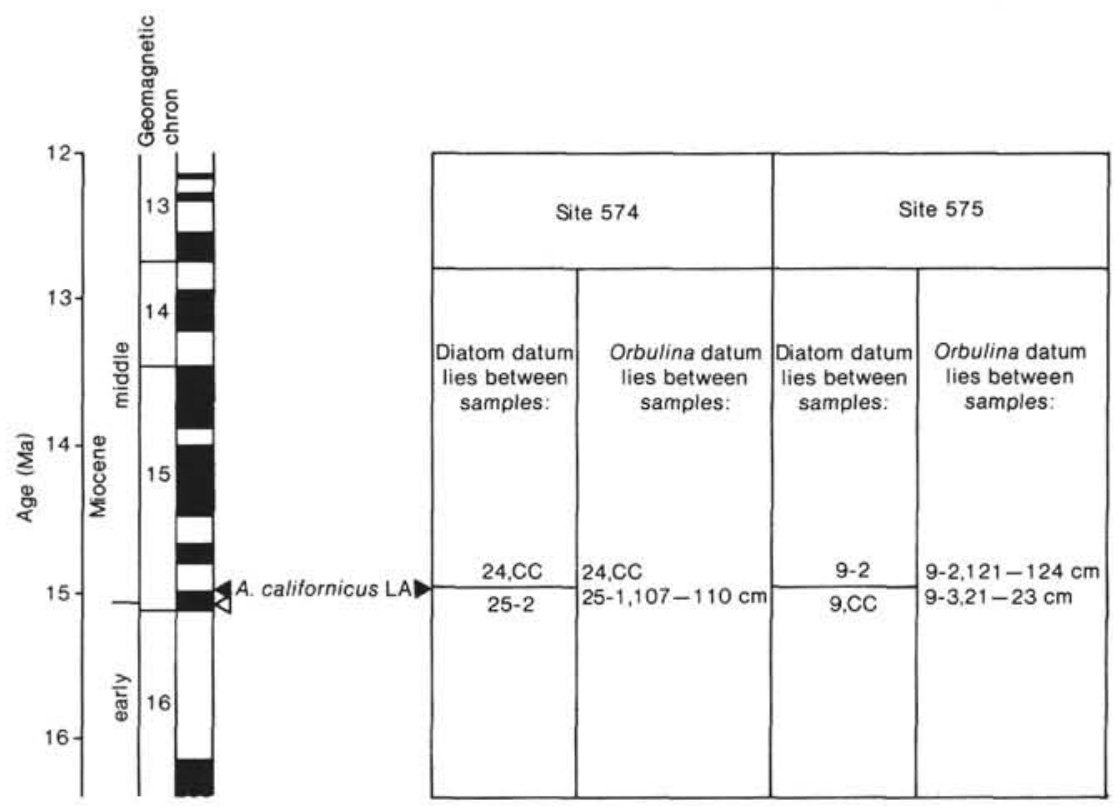

Figure 3. Comparison of stratigraphic levels of the Orbulina first appearance datum with the last appearance datum of Annellus californicus (solid triangle) at Sites 574 and $575 . \mathrm{Pa}$ leomagnetic scales after LaBrecque et al. (1977) with radiometric dates revised by Mankinen and Dalrymple (1979). The open triangle denotes the stratigraphic position of the first appearance level of Orbulina spp. as indicated by Poore et al. (1983).

Our examination of planktonic foraminifers and diatoms (Barron, this volume) in the continuously HPCcored sequences of Leg 85 sheds additional light on the age and geomagnetic calibration of the Orbulina datum. We examined the evolutionary development of the genus Orbulina from its ancestor Globigerinoides sicanus (de Stefani) through the few species belonging to the genus Praeorbulina in Holes 574, 574A, and 575. The first appearance datum of $O$. suturalis is identified precisely in these holes and occurs at the following levels: between $574-24, C C$ and $-25-1,107-110 \mathrm{~cm}$; between $574-$ $22-6,77-79 \mathrm{~cm}$ and $-22-6,141-144 \mathrm{~cm}$; and between $575-9-4,70-72 \mathrm{~cm}$ and $-9-5,21-23 \mathrm{~cm}$.

Barron (this volume) used a secondary correlation and tied some diatom datum levels recognized in the Leg 85 cores to the geomagnetic reversal record. In recent years, several authors (e.g., Opdyke et al., 1974; Burckle, 1978) have succeeded in directly integrating sequences of diatom datum levels with the geomagnetic reversal records, mainly by using piston cores. Fortunately for diatomists, many cores that are suitable for paleomagnetic study also yield good diatom assemblages.

Figure 3 compares the Orbulina datum level recognized at Sites 574 and 575 with diatom datum levels of Barron (this volume). At both sites, the Orbulina datum falls within an interval where Barron draws the last occurrence horizon of Annellus californicus Tempère. In terms of geomagnetic reversal sequences, as discussed by Ness et al. (1980), the $A$. californicus extinction datum lies in the middle of Anomaly 5B in the lower part of geomagnetic Chron 15. This correlation would give an age of $14.8 \mathrm{Ma}$ for the Orbulina datum.

Burckle (1978) also discussed the position of the Orbulina datum relative to geomagnetic reversal records by using the range of $A$. californicus in two paleomagneti- cally dated cores, $\mathrm{RC13}-22$ and $\mathrm{RC} 13-24$ from the equatorial Pacific. In Core RC13-24, A. californicus first appears in geomagnetic Chron 16 and disappears in the lower part of Chron 15 (Burckle cited in Opdyke et al., 1974). Burckle in the same paper also examined the range of this species in Leg 9 cores (Site 77) and established its last appearance level in Section 77B-24-2. The foraminiferal study by Jenkins and Orr (1972) had shown that the first appearance level of $O$. universa d'Orbigny is in the core-catcher sample of Core 23 , immediately above the core section that was shown by Burckle to record the top of the range of $A$. californicus.

Thus, all the evidence available from Sites 77, 574, and 575 points to a remarkable coincidence between the extinction level of $A$. californicus and the first appearance of $O$. suturalis and $O$. universa. This line of evidence further indicates that the Orbulina datum must lie within the lower part of geomagnetic Chron 15 with an approximate age of $15 \mathrm{Ma}$.

Poore et al. (1983) recently made direct calibrations of magnetostratigraphy and biostratigraphy for much of the latest Cretaceous to Cenozoic sequence based on HPC cores recovered during Leg 73. Their text-figure 4 indicates that the first appearance level of Orbulina spp. does indeed occur in Chron 15 within the normal polarity interval of Anomaly 5B.

\section{REFERENCES}

Akers, W. H., 1955. Some planktonic foraminifera of the American Gulf Coast and suggested correlations with the Caribbean Tertiary. J. Paleontol., 29:647-664.

Akers, W. H., and Dorman, J. H., 1964. Pleistocene foraminifera of the Gulf Coast. Tulane Stud. Geol. and Paleontol., 3:1-93.

Banner, F. T., and Blow, W. H., 1965. Progress in the planktonic foraminiferal biostratigraphy of the Neogene. Nature (London), 208: 1164-1169. 
Beckman, J. P., 1971. The foraminifera of Sites 68 to 75. In Tracey, J. I., Jr., Sutton, G. H., et al., Init. Repts. DSDP, 8: Washington (U.S. Govt. Printing Office), 713-726.

Berger, W. H., and von Rad, U., 1972. Cretaceous and Cenozoic sediments from the Atlantic Ocean. In Hayes, D. E., Pimm, A. C., et al., Init. Repts. DSDP, 14: Washington (U.S. Govt. Printing Office), 787-954.

Berggren, W. A., 1969. Paleogene biostratigraphy and planktonic foraminifera of northern Europe. In Brönnimann, P., and Renz, H. H. (Eds.), Proc. First Internat. Conf. Planktonic Microfossils: Leiden (Brill), pp. 121-160.

1972. A Cenozoic time-scale-some implications for regional geology and palaeobiogeography. Lethaia, 5:195-215.

1984. Correlation of Atlantic, Mediterranean, Indo-Pacific Neogene stratigraphics: geochronology and chronostratigraphy. In Ikebe, N., and Tsuchi, R. (Eds.), Pacific Neogene Datum Planes: Tokyo (Univ. Tokyo Press), pp. 93-110.

Berggren, W. A., and Van Couvering, J. A., 1974. The late Neogene: biostratigraphy, geochronology and paleoclimatology of the last 15 million years in marine and continental sequences. Palaeogeogr. Palaeoclimatol. Palaeoecol., 16:1-216.

Bermudez, P. J., and Seiglie, G. A., 1967. A new genus and species of foraminifer from the early Miocene of Puerto Rico. Tulane Stud. Geol. and Paleontol., 5:177-179.

Blow, W. H., 1956. Origin and evolution of the foraminiferal genus Orbulina d'Orbigny. Micropaleontology, 2:57-70.

1965. Clavatorella, a new genus of the Globorotaliidae. Micropaleontology, 11:365-368.

1969. Late middle Eocene to Recent planktonic foraminiferal biostratigraphy. In Brönnimann, P., and Renz, H. H. (Eds.), Proc. First Internat. Conf. Planktonic Microfossils: Leiden, (Brill), pp. 199-422.

1970. Validity of biostratigraphic correlations based on the Globigerinacea. Micropaleontology, 16:257-268.

Blow, W. H., and Banner, F. T., 1962. Part 2: The mid-Tertiary (upper Eocene to Aquitanian) Globigerinaceae. In Eames, F. E., Banner, F. T., Blow, W. H., and Clarke, W. J., (Eds.), Fundamentals of Mid-Tertiary Stratigraphical Correlation: Cambridge (Cambridge Univ. Press), pp. 61-151.

1966. The morphology, taxonomy and biostratigraphy of Globorotalia barisanensis LeRoy, Globorotalia fohsi Cushman and Ellisor, and related taxa. Micropaleontology, 12:286-302.

Bolli, H. M., 1950. The direction of coiling in the evolution of some Globorotaliidae. Cushman Found. Foram. Res. Contrib., 1:82-89. 1957. Planktonic foraminifera from the Oligocene-Miocene Cipero and Lengua Formations of Trinidad, B. W. I. U.S. Nat. Mus. Bull., 215:97-124.

Brönnimann, P., 1951. Globigerinita naparimaensis n. gen., n. sp. from the Miocene of Trinidad, B. W. I. Cushman Found. Foram. Res. Contrib., 2:16-18.

Burckle, L. H., 1978. Early Miocene to Pliocene diatom datum levels for the equatorial Pacific. In Wiryosujono, S., and Marks, E. (Eds.), Proc. Second Working Group Mtg., IGCP Project 114 (Bandung, Indonesia), pp. 25-44.

Cita, M. B., and Blow, W. H., 1969. The biostratigraphy of the Langhian, Serravallian and Tortonian stages in the type-sections in Italy. Riv. Ital. Paleont. Strat., 75:549-603.

Cushman, J. A., and Jarvis, P. W., 1929. New foraminifera from Trinidad. Cushman Lab. Foram. Res. Contrib., 5:6-17.

Cushman, J. A., and Stainforth, R. M., 1945. The foraminifera of the Cipero Marl Formation of Trinidad, British West Indies. Spec. Publ. Cushman Lab. Foram. Res., 14:1-75.

de Stefani, T., 1952. Su alcune manifestizioni di idrocarburi in provincia di Palermo e descrizione di foraminiferi nuovi. Plinia, Palermo, Italy, 3(1950-1951):1-12.

Edmond, J. M., von Damm, K. L., McDuff, R. E., and Measures, C. I., 1982. Chemistry of hot springs on the East Pacific Rise and their effluent dispersal. Nature (London), 297:187-191.

Egger, J. G., 1893. Foraminiferen aus Meeresgrundproben, gelothet von 1874 bis 1876 von S. M. Sch. Gazelle. Abh. K. Bayer. Akad. Wiss. München, Math. Physik. Kl., 18:193-458.

Ehrenberg, C. G. 1861. Elemente des tiefen Meeresgrundes in Mexikanischen Golfströme bei Florida; über die Tiefgrund-Verhältnisse des Ozeans am Eingänge der Davisstrasse und bei Island. Monatsber. K. Preuss. Akad. Wiss. Berlin, pp. 222-240, 275-315.
Hardenbol, J., and Berggren, W. A., 1978. A new Paleogene numerical time scale. Am. Assoc. Pet. Geol. Stud. Geol., 6:213-214.

Hays, J. D., Saito T., Opdyke, N. D., and Burckle, L. H., 1969. Pliocene-Pleistocene sediments of the equatorial Pacific: their paleomagnetic, biostratigraphic and climatic record. Geol. Soc. Am. Bull., 80:1481-1514.

Hays, J. D., and Shipboard Scientific Party, 1972. An interpretation of the geologic history of the eastern equatorial Pacific from the drilling results of the Glomar Challenger, Leg 9. In Hays, J. D., et al., Init. Repts. DSDP, 9: Washington (U.S. Govt. Printing Office), 909-931.

Jenkins, D. G., and Orr, W. N., 1972. Planktonic foraminiferal biostratigraphy of the eastern equatorial Pacific-DSDP Leg 9. In Hays, J. D., et al., Init. Repts. DSDP, 9: Washington (U.S. Govt. Printing Office), 1059-1193.

Jenkins, D. G., Saunders, J. B., and Cifelli, R., 1981. The relationship of Globigerinoides bisphericus Todd 1954 to Praeorbulina sicana (de Stefani) 1952. J. Foraminiferal Res., 11:262-267.

Keller, G., 1980. Early to middle Miocene planktonic foraminifera datum levels of the equatorial and subtropical Pacific. Micropaleontology, 26:372-391.

1981a. Miocene biochronology and paleoceanography of the North Pacific. Mar. Micropaleontol., 6:535-551.

1981b. The genus Globorotalia in the early Miocene of the equatorial and northwestern Pacific. J. Foraminiferal Res., 11: $118-132$.

Keller, G., and Barron, J. A., 1983. Paleoceanographic implications of Miocene deep-sea hiatuses. Geol. Soc. Am. Bull., 94:590-613.

Koch, R. E., 1926. Mitteltertiäre Foraminiferen aus Bulongan, OstBorneo. Eclogae Geol. Helvetiae, 19:722-751.

1935. Namensänderung einiger Tertiär-Foraminiferen aus Niederländisch Ost-Indien. Eclogae Geol. Helvetiae, 28:557-558.

LaBrecque, J. L., Kent, D. V., and Cande, S. C., 1977. Revised magnetic polarity time scale for Late Cretaceous and Cenozoic time. Geology, 5:330-335.

Lamb, J. L., and Stainforth, R. M., 1976. Unreliability of the Globigerinoides datum. Am. Assoc. Pet. Geol. Bull., 60:1564-1569.

Loeblich, A. R., Jr., and Tappan, H., 1957. The new planktonic foraminiferal genus Tinophodella, and an emendation of Globigerinita Brönnimann. J. Washington Acad. Sci., 47:112-116.

Mankinen, E. A., and Dalrymple, G. B. 1979. Revised geomagnetic polarity time scale for the interval 0-5 m.y.B.P. J. Geophys. Res., $84: 615-626$.

Nakagawa, H., Niitsuma, N., Kitamura, N., Matoba, Y., Takayama, T., and Asano, K., 1974. Preliminary results on magnetostratigraphy of Neogene stage stratotype sections in Italy. Riv. Ital. Paleontol. Strat., 80:615-630.

Ness, G., Levi, S., and Couch, R., 1980. Marine magnetic anomaly timescales for the Cenozoic and Late Cretaceous: prècis, critique, and synthesis. Rev. Geophys. Space Phys., 18:753-770.

Opdyke, N. D., Burckle, L. H., and Todd, A., 1974. The extension of the magnetic time scale in sediments of the central Pacific Ocean. Earth Planet. Sci. Lett., 22:300-306.

Page, R. W., and McDougall, I., 1970. Potassium-argon dating of the Tertiary F1-2 stage in New Guinea and its bearing on the geological time-scale. Am. J. Sci., 269:321-342.

Parker, F. L., 1967. Late Tertiary biostratigraphy (planktonic foraminifera) of tropical Indo-Pacific deep-sea cores. Bull. Am. Paleont., 52:115-208.

Poore, R. Z., Tauxe, L., Percival Jr., S. F., LaBrecque, J. L., Wright, R., Petersen, N. P., Smith, C. C., Tucker, P. and Hsü, K. J., 1983. Late Cretaceous-Cenozoic magnetostratigraphic and biostratigraphic correlations of the South Atlantic Ocean: DSDP Leg 73. Palaeogeogr. Palaeoclimat. Palaeoecol., 42:127-149.

Quilty, P. G., 1976. Planktonic foraminifera DSDP Leg 34-Nazca Plate. In Yeats, R. S., Hart, S. R., et al., Init. Repts. DSDP, 34: Washington (U.S. Govt. Printing Office), 629-703.

Robinson, E., 1969. Geological field guide to Neogene sections in Jamaica West Indies. J. Geol. Soc. Jamaica, 10:1-24.

Ryan, W. B. F., Cita, M. B., Dreyfus-Rauson, M., Burckle, L. H., and Saito, T., 1974. A paleomagnetic assignment of Neogene stage boundaries and the development of isochronous datum planes between the Mediterranean, the Pacific and Indian oceans in order to investigate the response of the world ocean to the Mediterranean "salinity crisis." Riv. Ital. Paleontol. Strat., 80:631-688. 
Saito, T., 1976. Geologic significance of coiling direction in the planktonic foraminifera Pulleniatina. Geology, 4:305-309.

Saito, T., and Biscaye, P. E., 1977. Emendation of Riveroinella martinezpicoi Bermudez and Seiglie, 1967, and synonymy of Riveroinella with Cassigerinella Pokorny, 1955. Micropaleontology, 23: 319-329.

Saito, T., Burckle, L. H., and Hays, J. D., 1975. Late Miocene to Pleistocene biostratigraphy of equatorial Pacific sediments. In Saito, T., and Burckle, L. H. (Eds.), Late Neogene Epoch Boundaries: New York (Am. Mus. Nat. Hist.), pp. 226-244.

Saito, T., Thompson, P. R., and Breger, D., 1976. Skeletal ultra-microstructure of some elongate-chambered planktonic foraminifera and related species. In Takayanagi, Y., and Saito, T. (Eds.), Progress in Micropaleontology: New York (Micropaleontology Press, Am. Mus. Nat. Hist.), pp. 278-304.

1981. Systematic Index of Recent and Pleistocene Planktonic Foraminifera: Tokyo (Univ. Tokyo Press).

Scholle, P. A., 1979. A color guide to sandstones: a color illustrated guide to constituents, textures, cements, and porosities of sandstone and associated rocks. Mem. Am. Assoc. Pet. Geol., 28:1-201.

Spraul, G., 1963. Current status of the upper Eocene foraminiferal guide fossil, Cribrohantkenina. J. Paleontol, 37:366-370.

Srinivasan, M. S., and Kennett, J. P., 1981. A review of Neogene planktonic foraminiferal biostratigraphy: applications in the equatorial and South Pacific. In Warme, T. E., Douglas, R. C., and Winterer, E. L. (Eds.), The Deep Sea Drilling Project: A Decade of Progress. Spec. Publ. Soc. Econ. Paleontol. Mineral., 32:395-431. 1983. The Oligocene-Miocene boundary in the South $\mathrm{Pa}$ cific. Geol. Soc. Am. Bull., 94:798-812.

Stainforth, R. M., and Lamb, J. L., 1981. An evaluation of planktonic foraminiferal zonation of the Oligocene. Univ. Kans. Paleontol. Contrib., 104:1-42.

Stainforth, R. M., Luterbacher, H., Beard, J. H., and Jeffords, R. M., 1975. Cenozoic planktonic foraminiferal zonations and characteristics of index forms. Univ. Kans. Paleontol. Contrib., 62: $1-425$.

Steininger, F. F., 1981. The working group of the Palaeogene/Neogene boundary. G. Geol., 64:15-24.

Thalmann, H. E., 1942. Foraminiferal genus Hantkenina and its subgenera. Am. J. Sci., 240:809-820.

Theyer, F., and Hammond, S. R., 1974. The Cenozoic magnetic time scale in deep-sea cores: completion of the Neogene. Geology, 2: 487-492.

Thompson, R. R., and Saito, T., 1977. Pacific Pleistocene sediments: planktonic foraminifera dissolution cycles and geochronology. $\mathrm{Ge}$ ology, 2:333-335.

Todd, R., 1957. Smaller foraminifera. Geology of Saipan, Mariana Islands: Pt. 3, Paleontology. U.S. Geol. Surv., Prof. Paper, 280-H: 265-320.

Van Couvering, J. A., 1972. Radiometric calibration of the European Neogene. In Bishop, W. W., and Miller, J. A. (Eds.), Calibration of Hominoid Evolution: Edinburgh (Scottish Acad. Press), pp. 247-271.

Van Couvering, J. A., and Berggren, W. A., 1977. Biostratigraphical basis of the Neogene time scale. In Kauffman, E. G., and Hazel, J. E. (Eds.), Concepts and Methods of Biostratigraphy: Stroudsburg, PA (Dowden, Hutchinson \& Ross), pp. 283-306,

Wiesner, H., 1931. Die Foraminiferen der deutschen Südpolar-Expedition 1901-1903. In von Drygalski, E. (Ed.), Deutsche Südpolar Expedition 1901-1903: Berlin (de Gruyter), 10:53-165.

Date of Initial Receipt: 15 September 1983

Date of Acceptance: 23 August 1984

\section{APPENDIX \\ Taxonomic Notes}

Because most of the species identified in Tables 2 through 6 are commonly recognized and have been treated fully elsewhere, only those taxa pertinent to discussion are selected for discussion and to provide a reference for the original description. For the Recent and Pleistocene planktonic foraminifers, a complete taxonomic treatment can be found in Saito et al. (1981).

\section{Cribrohantkenina inflata (Howe) subsp. bermudezi (Thalmann)}

(Plate 1, Fig. 2)

Hantkenina (Cribrohantkenina) bermudezi Thalmann, 1942, pp. 812, $815,819$.

Remarks. Spraul (1963) reillustrated and reviewed all the known species of the genus Cribrohantkenina. This species is distinct in that each of its succeeding chambers is progressively inflated, with the final chamber becoming greatly inflated and bulbose in shape. It possesses an equatorially located primary aperture with supplementary areal apertures above.

\section{Hantkenina primitiva Cushman and Jarvis (Plate 1, Fig. 1)}

Hantkenina alabamensis Cushman var. primitiva Cushman and Jarvis, 1929 , p. 16 , pl. 3 , figs. 2,3 .

Remarks. This is an interesting species of Hantkenina whose earlier one or few chambers in the last whorl lack the characteristic spines of Hantkenina. Previous records of this species are from Virginia and Alabama of the United States, Trinidad, Morocco, Italy, Ecuador, and Tanzania.

\section{Cassigerinella martinezpicoi Bermudez and Seiglie}

Riveroinella martinezpicoi Bermudez and Seiglie, 1967, pp. 177-178, pl. 1, figs. 1-6.

Cassigerinella martinezpicoi (Bermudez and Seiglie) Saito and Biscay, 1977 , pp. 322-324, pl. 1, figs. 1-8; pl. 2, figs. 1, 2, 4 .

Remarks. This species, originally defined as a benthic foraminifer under the genus Riveroinella, has since been reassigned to the planktonic foraminiferal genus Cassigerinella. Quilty (1976) reported this species from Hole 319 (middle Miocene, Zone N9) and Hole 321 (late Oligocene, Zone P19) of Leg 34 under the names of Globorotalia (Turborotalia) scitula (Brady), n. subsp. and Cassigerinella sp., respectively. Hole 319 and 321 are also located in the eastern equatorial $\mathrm{Pa}$ cific but at a latitude of about $10^{\circ} \mathrm{S}$.

\section{Globigerinita glutinata (Egger)}

(Plate 2, Figs. 5, 6)

Globigerina glutinata Egger, 1893, p. 371, pl. 13, figs. 19-21. Globigerinita naparimaensis Brönnimann, 1951, p. 18, figs. 1-14. Tinophodella ambitacrena Loeblich and Tappan, 1957, p. 114, figs. 2-3.

Globigerinita incrusta Akers, 1955, p. 655, pl. 65, figs. 2A-D. Globigerina juvenilis Bolli, 1957, p. 110, pl. 24, figs. 5a-6.

Remarks. One of the unexpected findings in the planktonic foraminiferal biostratigraphy of Leg 85 sequences is the frequent occurrence of G. glutinata and G. uvula in the lower Miocene (Zone N4) sections at Sites 574 and 575 . These small species, with their smooth, glassy tests develop an umbilical cover plate called bulla or, in many instances, a full-grown supplementary chamber. The great variability of bulla gives $G$. glutinata many morphologic variations even within a single sample, ranging from $G$. juvenilis, which lacks a bulla, to $T$. ambitacrena and G. naparimaensis, both of which possess a fully inflated bulla with multiple infralaminal openings. $G$. incrusta has a medium-built, rectangular bulla with only four openings. $G$. juvenilis, as described from Miocene sediments containing $G$. fohsi robusta, is a well-lobulated form and shows a thin-lipped primary aperture. Forms representing these various morphologies are tabulated in Tables 2 through 6 under their respective species names to show the extent of morphologic variations.

\section{Globigerinita uvula (Ehrenberg)}

(Plate 2, Figs. 1-4)

Pylodexia uvula Ehrenberg, 1861, pp. 276-277, 308.

Globigerina bradyi Wiesner, 1931, pp. 133-134.

Globigerinita uvula (Ehrenberg) Saito, Thompson, and Breger, 1981, pp. $81-82$, pl. 24, figs. 3a-d.

Remarks. This species is common in temperate and subpolar assemblages of Recent seas. The frequent occurrence of this species in the equatorial assemblages of Leg 85 cores was quite unexpected. The species is most numerous in the Zone N4 assemblages and rapidly diminishes in other intervals. 


\section{Clavatorella bermudezi (Bolli)}

(Plate 1, Figs. 3, 4)

Hastigerinella bermudezi Bolli, 1957, p. 112, pl. 25, figs. 1a-c. Clavatorella bermudezi (Bolli) Blow, 1965, pp. 367-368, figs. $1-5$.

Remarks. Blow (1965) thought that Clavatorella evolved from a globorotaliid ancestor and thus erected a new genus with $H$. bermude$z i$ Bolli as its type species. Saito et al. (1976) showed that the genus Clavatorella developed from Globorotaloides hexagona (Natland) in the early Miocene by developing clavate chambers that extend in a radial direction. This species is also distinct in having coalesced umbilical flaps resembling a webbed foot. This species has been reported from equatorial DSDP sites from the Atlantic, Indian, and Pacific oceans.

\section{Globorotalia kugleri Bolli}

(Plate 1, Figs. 5, 6)

Globorotalia kugleri Bolli, 1957, p. 118, pl. 28, figs. 5, 6 .

Remarks. This biochronologically important species has received much attention and has been widely recorded from the tropics to temperate areas. Keller (1981) analyzed in detail morphologic variations and abundances of this species in the equatorial and northwestern Pacific regions.

\section{Globoquadrina eximia (Todd)}

(Plate 1, Figs. 8-10)

Globigerina eximia Todd, 1957 , p. 300 , pl. 78 , figs. $8 \mathrm{a}-\mathrm{c}$

Remarks. Three inflated globular chambers make up the last whorl of this species, giving rise to its rounded, triangular equatorial profile. These three chambers in the last whorl increase very rapidly in size, and they constitute a large portion of the test. This species has an umbilical tooth and is herein reassigned to the genus Globoquadrina. Another three-chambered form is Globigerina tripartita Koch, which ranges from the upper Eocene to possibly lower Miocene. However, $G$. tripartita differs from $G$. eximia in having a subquadrate equatorial profile and a narrower, semi-closed umbilicus. Also, $G$. eximia has a much younger stratigraphic range, occurring in sediments as young as the middle Miocene Zone N13. Since it was first described from the island of Saipan, this species has received only limited acceptance.

\section{Globigerina binaiensis Koch}

Globigerina? aspera Koch, 1926, p. 746, figs. 22a-c. Globigerina binaiensis Koch, 1935, p. 558.
Remarks. This species is a unique and very distinct planktonic foraminifer characterized by its remarkably flattened apertural face. Its last chamber is extraordinarily large compared with all the earlier chambers combined. The presence of a weak but distinct umbilical tooth suggests its taxonomic affinity with the genus Globoquadrina.

\section{Globigerina pseudovenezuelana Blow and Banner} (Plate 2, Figs. 7-9)

Globigerina yeguaensis Weinzierl and Applin subsp. pseudovenezuelana Blow and Banner, 1962, pp. 100-101, pl. 11, figs. J-L, N, O. Stainforth et al. (1975) considered G. pseudovenezuelana to be one of the species representing a closely knit plexus of integrating species from the form known as $G$. eocaena Guembel ( $=G$. yeguaensis Weinzierl and Applin) to the three-chambered G. tripartita Koch. They placed $G$. pseudovenezuelana in synonymy with $G$. venezuelana Hedberg. $G$. pseudovenezuelana is here distinguished in having more rounded chambers and more deeply depressed sutures than those of $G$. venezuelana. This species characterizes upper Eocene and Oligocene sequences of Leg 85 .

\section{Globigerinoides sicanus (de Stefani)}

Globigerinoides conglobatus (Brady), Cushman and Stainforth, 1945, p. 68 , pl. 13 , fig. 6 .

Globigerinoides sicana de Stefani, 1952, p. 9.

De Stefani (1952) erected $G$. sicanus with the designation as its type species of the specimen identified and figured by Cushman and Stainforth (1945) as G. conglobatus (Brady). The name G. sicanus remained in relative obscurity until Blow (1969) described it as having a taxonomic priority over the then widely used species $G$. bisphericus Todd. Since then, there has been a mixture of usage, some preferring $G$. sicanus and some favoring the old name $G$. bisphericus. Jenkins et al. (1981) examined the holotype specimens of these two species and concluded that $G$. sicanus should be classified under the genus Praeorbulina because of its possession of four slitlike apertures at the base of the final chamber. There is a possibility that $G$. sicanus is a senior synonym of P. glomerosa (Blow), because Blow (1956) included in the morphologic variation of his new species those forms having four slitlike apertures. Therefore, $G$. sicanus as used in this report follows the definition given by Stainforth et al. (1975) and includes those forms previously classified as $G$. bisphericus Todd. 


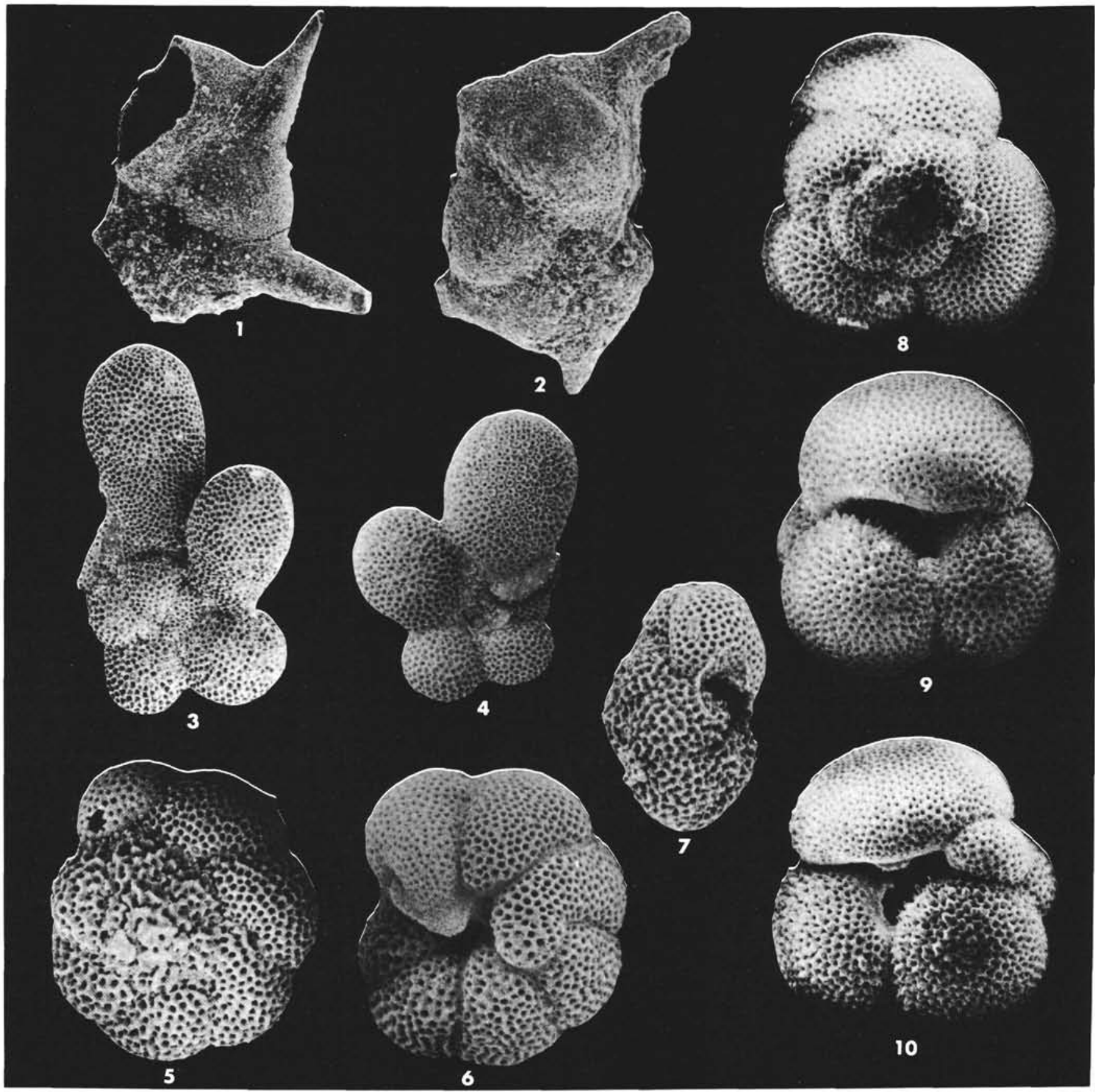

Plate 1. Cenozoic planktonic foraminifera. 1. Hantkenina primitiva Cushman and Jarvis, side view, $\times 146$, Sample 573B-42-4, 140-144 cm, upper Eocene. 2. Cribrohantkenina inflata bermudezi (Thalmann), side view, $\times 146$, Sample 573B-42-4, 123-124 cm, upper Eocene. 3-4. Clavatorella bermudezi (Bolli), spiral and umbilical side views, $\times 107$, Sample 574A-20,CC, middle Miocene. 5-7. Globorotalia kugleri Bolli, spiral side, umbilical side, and side views $\times 230$, Sample 575A-33,CC, lower Miocene. 8-10. Globoquadrina eximia (Todd), spiral side, umbilical side, and umbilical side views, $\times 107$, Sample 574-28,CC, lower Miocene. 


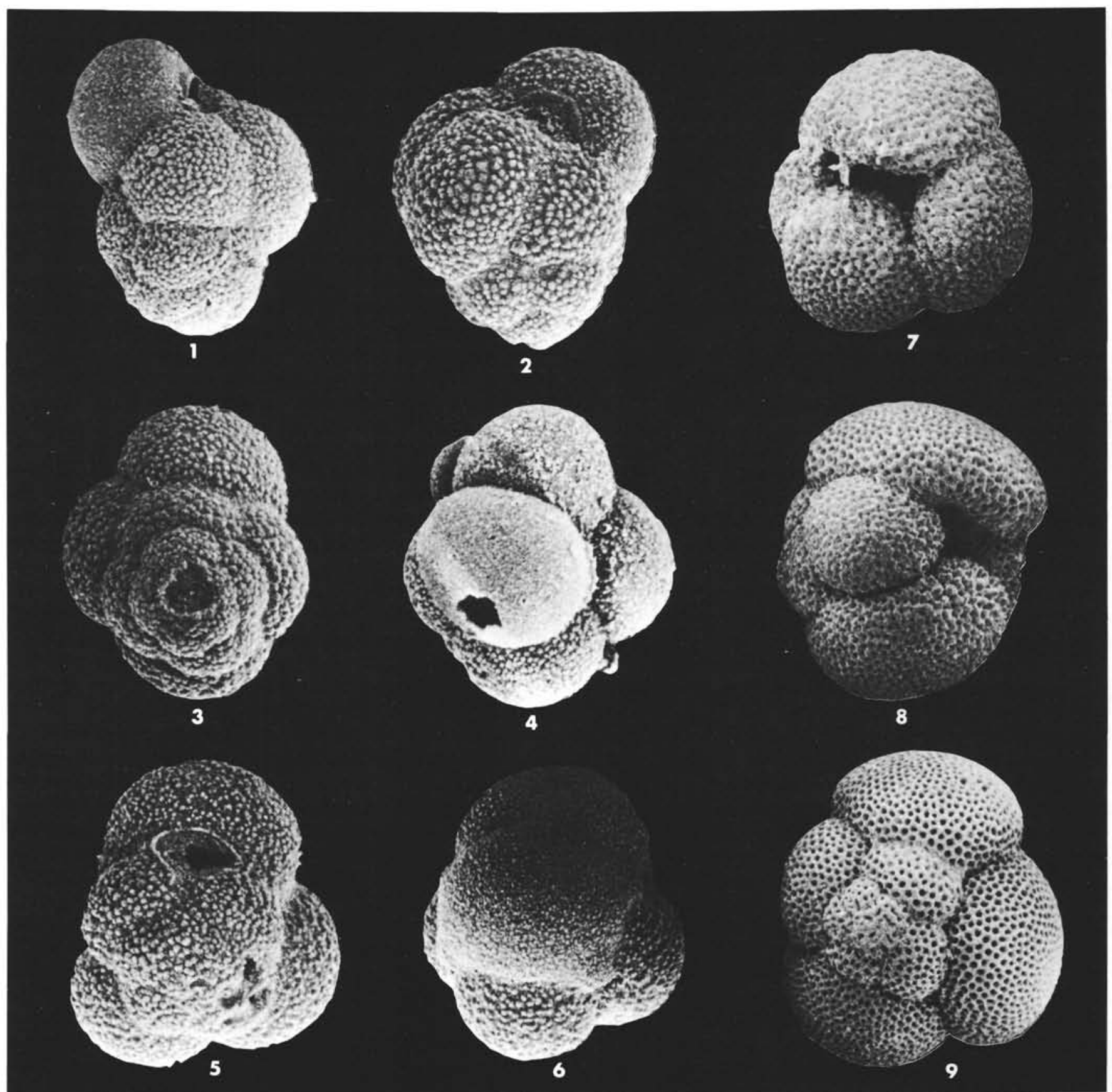

Plate 2. Cenozoic planktonic foraminifera. 1-4. Globigerinita uvula (Ehrenberg), two side, spiral side, and umbilical (covered by a bulla) side views, $\times 338$, Sample 575A-33,CC, lower Miocene. 5-6. Globigerinita glutinata (Egger), $\times 338$, Sample 575A-33, CC, lower Miocene (5, specimen resembling Globigerinita parkerae (Bermudez) in having a bulla-covered supplementary aperture on spiral side; 6 , umbilical side view of specimen having a bulla with four infralaminal apertures). 7-9. Globigerina pseudovenezuelana Blow and Banner, umbilical side, side, and spiral side views, $\times 107$, Sample 574C-29,CC, lower Oligocene. 